\title{
Fighting for Talent: Risk-Taking, Corporate Volatility, and Organizational Change*
}

\author{
Guido Friebel \\ University of Toulouse (EHESS and IDEI) \\ and CEPR
}

\author{
Mariassunta Giannetti \\ Department of Finance \\ Stockholm School of Economics \\ CEPR and ECGI
}

August 14, 2006

\begin{abstract}
*We would like to thank Abhijit Banerjee, Mike Burkart, Yrjö Koskinen, Christian Laux, Michael Raith, Avri Ravid, Åsa Rosén, Sarbajit Sengupta, Lucy White, and seminar participants at the Western Finance Association (Los Cabos), the CEPR European Summer Symposium in Financial Markets (Gerzensee), Harvard Business School Conference on Entrepreneurship and Innovation, the CEPR Conference on Organizational Behaviour, Structure and Change (Toulouse), the RICAFE conference (Frankfurt), the IZA Conference on Interactions of Financial and Labor Markets (Bonn), the CES/IFO Summer Institute, the European Economic Association and the Econometric Society Meetings in Venice, the Stockholm School of Economics, the Norwegian School of Economics and Business Administration (Bergen), Stockholm University, University of Lugano, the University of Zurich, the Athens University of Economics and Business, and the Federal Reserve Bank of Saint Louis for their comments. Giannetti acknowledges financial support from the Jan Wallander och Tom Hedelius Foundation and the Riksbanken Jubileum Foundation. All errors are ours. Correspondence to: University of Toulouse, Manufacture des tabacs, 21 allee de Brienne, FR 31000 Toulouse, E-mail: friebel@cict.fr Phone: + 33-5-61128605 (Friebel) or Stockholm School of Economics, Sveavägen 65, Box 6501, SE-113 83, Stockholm, Sweden. E-mail: mariassunta.giannetti@hhs.se Phone: +46-8-7369607 (Giannetti)
\end{abstract}




\begin{abstract}
During the nineties, talented workers began to spurn secure jobs in large organizations, which were formerly considered prestigious. They developed more positive attitudes towards jobs in small, innovative startups, although these involved less job security. We build a model that identifies some of the economic forces behind the shift in the supply for talent from large to small firms. Small firms with little capital at stake take excessive risk. They realize more of their workers' risky ideas, which allows to poach creative workers from better capitalized firms. We show that small firms' advantage in attracting creative workers emerges if ideas have ex ante positive net present value and increases if workers can smooth consumption through financial markets. As small firms take excessive risk, average enterprise profitability in the affected sectors decreases, while bankruptcy increases. Moreover, large firms react through inefficient organizational changes. We also provide some empirical evidence consistent with the implications of our theory.
\end{abstract}

Keywords: Occupational choice, spin-offs, sorting in labor markets, organizations and markets, financial development

JEL Classification Numbers: L2, G3 


\section{Introduction}

The nature of the firm has changed substantially in the last decade. Asset-intensive, highly vertically integrated firms with tight control over their employees have become old-fashioned. Instead, human capital and the skills of workers have become crucial in determining corporate success (Rajan and Zingales, 2002). Firms have thus entered into fierce competition for the most talented and creative employees. However, retaining talented workers has proved to be a difficult task, because their preferences for different types of jobs have been changing over time.

Surveys during the nineties show that talented workers expected opportunities for personal growth from their jobs, and from their organization that it "encourages to challenge the way things are done" (Stum, 1998). Cappelli (1999, p. 228) reports that an increasing number of MBAs from top U.S. business schools were declining job offers with the highest pay, such as positions in investment banking and consulting. Rather they were taking jobs in small companies and start-up ventures. MBAs became more willing to forgo job security in order to gain the "possibility of hitting it big". Talented workers began to spurn secure jobs in large and stable organizations ${ }^{1}$, formerly considered prestigious. Cappelli concludes that MBAs' "willingness to roll the dice for a big reward" increased. ${ }^{2}$ The anecdotal evidence indicates that the supply of talent shifted from large to small firms. This is also reflected in survey data. In 1989, 94 percent of U.S. workers of very different skills answered that they considered job security important or very important. In 1997, only 90 percent thought so. Similar tendencies were observed in other countries such as the U.K. (International Social Survey Programme, 1989, 1997; Malone, 2003).

Changes in worker attitudes and occupational choice coincided with an increase in small firms employment and decreasing average firm size, in particular, in the high-tech sectors of OECD countries (Pryor, 2001). Large firms, attempting to attract the most skilled workers, tried to imitate the way small firms operate by creating spin-offs (Lawler et al., 1995; Michaels et al., 2001). ${ }^{3}$ Some of these attempts were of rather short-term nature. After the burst of the new economy bubble, large firms have become more attractive again. Similarly, some of the most extreme changes of

\footnotetext{
${ }^{1}$ Caves (1998) shows that the mortality rate of firms is decreasing with age and size.

${ }^{2}$ Cappelli also reports that confronted with the hypothetical alternative between a risky job involving a possibly big payoff or a secure one, MBAs became increasingly prone to the risky choice, even if the expected compensation was not much higher than in the secure job.

${ }^{3}$ A prominent example of this "small-is-beautiful" tendency was the Bertelsmann Group, which even created its own venture fund (Day et al., 2001).
} 
the nineties have been reversed and large companies are dismantling their corporate venture funds (The Economist, 2001).

We present a theory that aims to identify the driving forces behind the coincidence of talent supply shift and changes in worker attitudes towards large and small firms. The explanation we bring forward is based on two forces: talented workers care for realizing their ideas, but they also wish to be insured against income risks. Financial market development makes household credit more easily accessible. Then, talented workers become less averse to the income risk of working in less capitalized organizations that are more likely to default. As small firms are more inclined to fund risky projects, they then acquire a competitive edge for poaching the most creative workers who care for realizing their own ideas. Technological progress has a similar effect. It raises the expected payoff from realizing workers' ideas. When ideas' expected payoff becomes ex ante positive (that is, positive even without screening), small firms are able to raise external funding to realize risky ideas and thus start to be attractive for creative workers.

We view our theory as complementary to the ones that stress the importance of financial development on the availability of capital for small firms and start-ups (see, for instance, Zingales, 2000). The relevance of this mechanism is undeniable, but it does not explain the documented changes in worker attitudes towards large and small firms. An increase in the number of start-ups induces higher demand for talent from small firms and could account for the increasing employment share of small firms. However, it does not explain why talented workers would spurn large organizations and the security they offer. If anything, jobs in large firms should have become more desirable because they became scarcer. Small firms should then have faced stronger competition to attract talent than large firms. The empirical evidence, however, suggests the opposite. We believe that understanding the determinants of the shift in the supply of talent to small firms is important, because the role of human capital for innovation is at least as large as the role of financial capital (Mohnen and Roeller, 2005).

In our model, the key to the comparative advantage of small firms is their risk-taking. Large firms tend to have more self-financed assets than small firms. Jensen and Meckling (1976) have shown that less capitalized firms have stronger incentives to choose riskier projects. As funding a worker's idea involves the risk of losing the initial investment, a firm will be less prone to fund risky ideas when more of its assets, its reputation or future cash flows of other projects are at stake. For 
this reason, larger firms are more careful in screening their employees' ideas. ${ }^{4}$ Large firms accept less bad ideas, but they are also more likely to reject good ideas. Their screening behavior is ex post optimal from the point of view of maximizing the return to investment, but it has important ex ante implications on the attractiveness of jobs in large firms. Small firms can use their higher propensity to realize workers' ideas in a similar way as variable pay, the positive effect of which on sorting of workers has been highlighted by Lazear (1986, 2001). Large firms cannot commit themselves to offer jobs in which workers realize as many of their ideas as they could in small firms. This is particularly important for the most creative workers, who are the most concerned to see their ideas realized, in order to show their ability and to receive higher wages. Nonetheless, any worker also appreciates the insurance that jobs in large firms can provide.

Workers thus face a trade-off between better insurance and lower probability of realizing their own ideas. How this trade-off affects the choice of workers between jobs in small and large firms depends on the possibility of insurance offered by the financial market and on technological change.

First, consider that liquidity constraints of households relax, as happened in the U.S. during the nineties. ${ }^{5}$ Then, the propensity of creative workers to work in large firms decreases. In fact, if their idea turns out to be bad and their firm defaults, they can borrow against their future income, while looking for a new job. This implies that better access to household credit, because of financial development or a booming economy or both, ${ }^{6}$ makes the insurance offered by large firms less desirable. Small firms thus gain a competitive edge over larger firms in attracting creative workers.

Second, consider the effects of technological change that affects the expected payoff from realizing new ideas of workers. If this expected payoff is negative before screening, small firms cannot access external capital to fund workers' ideas. All the ideas that come up are then funded in large firms that can employ as many creative workers as they wish. But when the expected payoff of ideas increases, funding an idea becomes a project with positive net present value. This reduces the capability of large firms to attract the most talented workers, because screening involves that

\footnotetext{
${ }^{4}$ As will become clear, more intensive screening by large firms is a result, not an assumption of our theory. In addition, Subsection VI.A presents empirical evidence consistent with it.

${ }^{5}$ The process of financial deregulation made consumer access to credit markets easier. As a consequence, the liabilities of households increased substantially over the nineties, especially in the U.S., see Guiso et al. (2002) and Sullivan (2001). Section VII provides further references and evidence.

${ }^{6}$ Notice that during expansions, the value of real estate is higher and mortgages can be more easily increased.
} 
ideas with positive net present value are sometimes rejected. The most talented workers then prefer to work in small firms that do not screen, although the entry wage differential between large and small firms increases.

Better access of households to capital markets and technological change may thus affect average enterprise profitability negatively in sectors in which worker talent is important. In our model, better access to credit and technological change raise the number of ideas that are funded, as small firms are less choosy in accepting new projects. When too many ideas are funded, the variance of small firms' profits increases, and there are more bankruptcies. The source of this inefficiency is that small firms do not fully internalize the cost of investment. This is suboptimal from the point of view of maximizing gross output, but benefits the more creative workers.

The desire of creative workers to realize their ideas may also spur changes in capital and organizational structure in the wrong direction. Large and well-capitalized firms lose their most creative workers and become less profitable, although their conservative behavior in project selection is good for the economy. Small risk-loving firms may have higher per-capita profits than large firms, because they attract more creative workers. The loss of competitiveness of large firms may force them to change their organizations. In particular, in order to commit to adopting less intensive screening processes, large firms may buy back stocks and increase leverage in order to operate more similarly to small firms. Additionally, and perhaps more importantly, large firms may have an incentive to create spin-offs that - being less capitalized - behave more like small firms.

Finally, we provide original empirical evidence showing that the main predictions of our theory are in line with U.S. data. Individuals with less tight credit constraints, that is, with large unused credit capacities are more likely to be self-employed or employed in small firms. We also carry out a series of robustness checks. In particular, we show that the effect of credit-constraints is statistically not different from nil for workers who carry out routine tasks. But it is both statistically and economically significant for workers with managerial or research-related tasks, arguably the group for which creativity matters most. We also show that proxies for the expected payoff of new ideas have the effect that the theory predicts.

The remainder of the paper is organized as follows: Section II relates the paper to the literature. Section III describes the model; Section IV derives the equilibrium and highlights some implications. Section V discusses to what extent assumptions can be relaxed. It also suggests some extensions. 
Section VI discusses how our theory relates to observations concerning organizational change, and gathers some existing empirical evidence in support of the model. Section VII contains the original empirical evidence. Section VIII concludes.

\section{Related literature}

The main contribution of the paper is to show that the availability of finance affects corporations not only through financial markets, but also through the labor market. ${ }^{7}$ Rajan and Zingales (2001) argue that better developed financial markets decrease collateral requirements and thus make it easier for start-ups to access external finance. Hurst and Lusardi (2004) show that this common wisdom is, surprisingly, not supported by data. They find that availability of initial capital, proxied by an individual's initial wealth, does not affect the decision to become an entrepreneur and rationalize this by the small amount of capital necessary to start a new business. Our model suggests another channel why financial development may matter: it shows that access to consumer credit also affects the choice of workers to sort into small or large firms and may harm large firms because of a labor-stealing effect.

Interestingly, workers' choices between small and large firms may change over the business cycle if the level of access to consumer credit changes. We thus provide a new rationale why easier access to consumer credit may increase the volatility of an economy. The macroeconomic literature has stressed that easing liquidity constraints, by favouring indebtedness of households, has made them more sensitive to changes in the interest rate, income, and asset prices (Debelle, 2004). We here suggest that the mere possibility of accessing consumer credit affects households' preferences over jobs and the risk-taking of both households and firms.

We also show that under certain conditions it may be optimal for large companies to create spin-offs. To this extent, our paper contributes to the literature studying the conditions under which it is optimal to decentralize production. We show that when workers are differing in creativity, companies may have an incentive to spin off some of their activities not only to affect workers ex post incentives to provide efforts, as, for instance, in Scharfstein and Stein (2000), and Gromb

\footnotetext{
${ }^{7}$ Related to this is the work by Fortin (1995) and Del Boca and Lusardi (2003). They show that following financial market liberalization, the use of mortgages by households has increased, involving increased female labor participation.
} 
and Scharfstein (2002), but also to influence workers' ex ante occupational choice. Our paper is also related to Laux (2001) who shows that spinning off a highly indebted subsidiary is a commitment device for the principal to monitor the manager of the subsidiary. We show that if ex ante sorting and occupational choices rather than ex post incentives are important, the contrary may be true: spin-offs funded with external funds may be a commitment device not to screen projects too intensively (in order to attract creative workers).

In our model, large firms lose their competitiveness in the labor market because they screen too carefully, that is, they acquire "too much" information relative to small firms. This is related, but not identical, to the effect pointed out by Crémer (1995) and Aghion and Tirole (1997). ${ }^{8}$ They point out that less information acquisition by the principal can be desirable as it strengthens worker incentives. In contrast, in our model, information acquisition is always optimal with respect to maximizing the return to investment. It also does not adversely affect the payoff of the idea, which is exogenous. Nonetheless, more information acquisition may be bad for a firm as it makes it harder to recruit talented workers. It may then be optimal to spin off units, because this is the only way to commit to increased risk-taking as desired by the most creative workers.

\section{The Model}

We first describe the essentials of the model. We then present the timing and finally define the equilibrium. The model presented here is the most tractable framework in which we can obtain our results. Technical assumptions are relegated to Section IV in which we derive the equilibrium; the relevance of the most important economic assumptions and the robustness of the model are discussed in Section V. All proofs are in the Appendix.

\section{A Essentials}

We consider an economy in which there is a set of workers of mass 1 , one large firm and free entry of small firms. All firms have access to the same technologies. First, there is a risk-free, traditional technology in which capital and labor are perfect substitutes. All workers have the same productivity when employed in the risk-free technology, which yields return $r(\underline{w})$ per unit of

\footnotetext{
${ }^{8}$ A similar point, applied to internal capital markets, is made by Stein (2002).
} 
capital (per worker). All workers have access to this technology. As labor and capital are substitutes in the traditional technology, $\underline{w}$ can be seen as an economy-wide reservation wage.

Second, there is a risky technology that can only be used if a firm hires a worker who (after hiring) has an idea. ${ }^{9}$ If the firm decides to realize the idea, the worker cannot work with the traditional technology at the same time. Firm and worker are complementary in the realization of the idea: the worker cannot realize her idea outside of the firm; and the firm needs the worker to realize the idea. Ideas can be either profitable (good, $G$ ) or not (bad, $B$ ). The prior probability of an idea being good is $\alpha$. If a firm funds a good idea by investing $I$, it generates revenue $Y$, while if it is bad, it generates a return of nil. New ideas have positive net present value if they have higher expected returns than employing the capital and the worker in the traditional risk-free technology, that is, $Y>\frac{I(1+r)+\underline{w}}{\alpha}$. We first assume that ideas have positive net present value. In Section V, we describe how the equilibrium changes if this condition is not satisfied.

Concerning capital supply, we assume that the large firm has an initial amount of self-financed assets $A^{L}$ which is sufficient to finance internally any number of projects. The number of workers in the large firm will be determined in equilibrium. Small firms have no assets and hence need outside capital. ${ }^{10}$ Each small firm is assumed to hire one worker. All firms have access to a competitive capital market in which investors are endowed with infinite amount of capital. ${ }^{11}$ Loans to small firms must provide investors with an expected return equal to $r$, the rate of return of a risk-free asset. ${ }^{12}$ Hence, no firm has an incentive to borrow in order to invest in the traditional technology, because the return of capital in the traditional technology is also $r$. All assets of small firms are consumed in realizing the project. Thus, investors recover nothing of their investments when an idea is bad. Investors have correct beliefs on firms' screening and funding decisions. The nominal value of their claim, $D^{S}$, must hence satisfy the participation constraint of investors, $D^{S} \geq \frac{(1+r) I}{\widehat{\alpha}}$. Here, $\widehat{\alpha}$ is the belief about the probability of a realized idea being good. If a project is not screened

\footnotetext{
${ }^{9} \mathrm{~A}$ worker's idea consists of a product or process innovation that may increase the expected profits of the firm. This is in line with the broad interpretation of value-improving innovations in organizational economics. See, for instance, Rotemberg and Saloner (2000).

${ }^{10}$ We make the assumptions about capital endowment of the large and the small firms for the sake of simplicity and clarity. In principle we can allow for the large firm to be partially outside financed, or conversely, for small firms to have some internal funds. We discuss this in Subsection V.D.

${ }^{11}$ Infinitely elastic supply of capital implies that the sector we are looking at is small with respect to the overall economy. This assumption is common in small open economy models and general equilibrium models analyzing specific sectors of the economy like ours (see Michelacci and Suarez, 2004).

${ }^{12}$ Note that in our model, ideas either fail or succeed once their are funded. Hence, as there are only two states of the world, debt and equity are equivalent.
} 
prior to carrying it out, then, $\widehat{\alpha}=\alpha$.

Workers differ in the probability of having an idea, $\phi$. Parameter $\phi$ can be understood as a measure of creativity, uniformly distributed on the support $[0,1]$. Workers know their type $\phi$. Prior to recruitment, firms cannot identify $\phi$, and workers cannot signal their type. Hence, workers will self-select into the large firm or into any of the identical small firms, given the wage firms offer and their beliefs about the chances of realizing an idea in the large $v s$ small firms. For the sake of simplicity, we assume that the quality of the idea is the same for all workers. Thus, between workers and firms the only asymmetry of information concerns the probability of an idea, while there is symmetric uncertainty about its quality.

\section{B Timing}

Firms and workers live two periods. Firms are risk-neutral; workers are risk-averse.

\section{First Period}

Contract stage. At $t=0$, firms offer a wage contract. For tractability, we assume that the worker's compensation depends only on whether or not the firm defaults, and whether or not an idea is successfully implemented. ${ }^{13}$ There are then three different levels of compensation. First, the large (small) firm commits itself credibly to pay a fixed wage $w_{1}^{L}\left(w_{1}^{S}\right)$ provided that it does not default. Second, in case of default, the compensation is nil. Third, in case an idea is implemented, worker and firm bargain over the division of the surplus. The firm receives a part $\lambda$, and the worker $(1-\lambda)$ of the surplus (net of financing costs). ${ }^{14}$ For small firms, financing costs are equal to $D^{S}$. For the large firm, which finances $I$ with internal funds, we set financing costs equal to the alternative return of investment, $I(1+r) \cdot{ }^{15}$ If an idea is successfully realized, the worker does not receive the fixed wage. We could also assume that the worker receives a fixed wage in all states of the world, but our notation makes further steps of analysis most convenient. Notice that our assumptions imply that the workers share of the surplus must be larger than the fixed wage, which we assume

\footnotetext{
${ }^{13}$ Our contracts are incomplete in the sense of Grossman and Hart (1986): we do not allow for wages to be made contingent on the occurence of an idea, nor on the decision of a firm to fund an idea. Neither can payments be made contingent on other decisions firms or investors may take. We discuss in Subsection V.A the importance of our assumptions about contractibility of wages and to what extent we could relax them.

${ }^{14}$ We do not explicitly model the bargaining game between the firm and the worker. One may think that the share of surplus accruing to the worker and the firm, respectively, depends on the relative importance of their effort in order to realize a successful idea.

${ }^{15}$ This assumption keeps the notation as simple as possible. All results would be qualitatively similar if the cost of investment in the large firm incorporated the risk of default.
} 
throughout the paper.

Occupational choice. At $t=1$, workers make their occupational choice. They either choose the large firm or any of the identical small firms. A worker's programme, subject to the budget constraints (1) and the liquidity constraint (2) is:

$$
\begin{aligned}
\max _{\left\{c_{1}, c_{2}, b, f\right\}} E_{1}(U) & =E_{1}\left(u\left(c_{1}\right)+\frac{1}{1+\delta} u\left(c_{2}\right)\right) \\
\text { s.t. } \widetilde{w}_{1}(f, i)-b & =c_{1} \\
\underline{w}+(1+r) b & =c_{2} \\
b & >-B .
\end{aligned}
$$

Workers are risk averse: $u^{\prime}>0, u^{\prime \prime}<0 ; \delta$ is the intertemporal discount rate. The worker's consumption (compensation) in period $t$ is denoted $c_{t}\left(w_{t}\right)$. Compensation $\widetilde{w}_{1}$ is a random variable the probability distribution of which depends on the type of firm the worker chooses, $f \in$ $\{S=$ small, $L=$ large $\}$, and on whether the worker will have an idea $(i=1)$ or not $(i=0)$. Workers' first-period savings (bonds) are $b \equiv \widetilde{w}_{1}-c_{1}$, and $r$ is the risk-free interest rate at which a worker can borrow and lend. Workers decide on first-period consumption and whether to borrow or save after first-period compensation is realized.

Because $u($.$) is concave, workers want to smooth consumption over periods. We assume \delta=$ $r$. Hence, there are no incentives to borrow and lend other than consumption smoothing. The liquidity constraint (2) implies, however, that workers may not be able to borrow as much as they want against future wage. We can then model the impact of financial market development in a straightforward way: the easier is access to consumer credit, the larger is the amount $B$ that workers can borrow against their future wages. Clearly, an increase in $B$ affects the consumption path and occupational choice only if the borrowing constraint is binding. We will assume this throughout the paper and investigate how changes in the borrowing constraint affect occupational choice.

Idea. At $t=2$, each worker has an idea with probability $\phi$. Workers always have an incentive to communicate their idea to the employer ${ }^{16}$ and cannot pretend to have an idea if they do not. However, neither the worker nor the firm know whether the idea is good.

\footnotetext{
${ }^{16}$ This readily follows from the fact that the worker's share of the idea surplus is assumed to be larger than the wage and the worker can choose to work in a large firm to avoid downside risk.
} 
Screening and investment. At $t=3$, the profit-maximizing firms choose whether to screen the idea submitted by the worker prior to deciding whether to fund it. Screening involves a cost $c$. A firm that screens receives a signal about the quality of the idea and updates its belief about the quality. Firms decide which technology to invest in, eventually after observing the signal of the screening technology. If needed, investors provide capital to fund ideas. Investors can neither observe nor verify screening decisions. ${ }^{17}$

Output and payoffs. At $t=5$, output is realized. If the worker (capital) has been employed in the traditional technology, safe returns $\underline{w}(r)$ are realized. The worker receives the contractually stipulated fixed wage. If a firm goes bankrupt because an idea failed, workers and firms receive nil. If an idea was funded and is successful, worker and firms share the surplus after payment of investors. To make the distinction between the large and the small firms meaningful, and to model the insurance function of the large firm as simply as possible, we assume that the large firm never defaults. Rather, it has enough capital to pay wages $w_{1}^{L}$ to all their workers even if all ideas fail. To put it formally: $A^{L} \geq\left(I+w_{1}^{L}\right)$. After receiving their compensation (or nothing), workers can borrow up to an exogenously fixed amount. Then, they consume.

\section{Second Period}

At $t=6$, all workers and assets are employed in the traditional technology. Workers pay back their loans or receive interests on their savings, and consume.

\section{Equilibrium}

The equilibrium is defined as follows:

- Workers maximize their expected utility by making consumption and borrowing decisions and by sorting themselves into the large or any of the identical small firms. Workers take wages as given. They have rational beliefs about the odds of realizing an idea in the large or in a small firm. They also have correct beliefs about the payoff from a successful idea.

- Both the large and small firms offer wages that maximize their expected profits. They take the wages of the other firms as given, but they internalize the effect of their wages on occupational choice.

\footnotetext{
${ }^{17}$ Firms would want to declare to their investors that they have screened intensively, but this is not credible.
} 
- Both the large and small firms choose whether to screen and fund an idea to maximize the expected profits from the implementation of an idea, after it has been submitted by the worker. It is an important feature of the equilibrium that firms cannot commit themselves ex ante to realize a worker's idea with a certain probability. Small firms take the cost of external funds as given.

- The capital market supplies any amount of capital demanded, provided that the expected return equals the return of the risk-free asset. The external financiers do not observe whether firms screen ideas, but have correct expectations about firms' screening decisions.

- The labor market clears. In particular, the mass of workers employed by the large firm is such that all the workers who prefer to work in the large firm are, in equilibrium, hired by the large firm. Also, anybody who wants to work in a small firm finds a firm that employs him or her.

In what follows we focus on an equilibrium in which the sets of workers employed in the large firm and in small firms are non-empty. We determine conditions on the parameters under which this is true.

\section{Equilibrium and its implications}

We solve the model backwards. We first investigate the large and small firms' respective screening and investment decisions $(t=3)$. Then, we look at workers' occupational choice $(t=1)$. Finally, we determine what wages firms offer $(t=0)$.

A first observation allows us to set $w_{1}^{S}=\underline{w}$. Recall that firms compete for workers. They can commit themselves to pay a fixed wage, while in the case of success, surplus is shared according to the bargaining power of workers and firms. First, in this setting, no worker would accept a wage below $\underline{w}$ from a small firm, because there would always be another small firm willing to pay an $\varepsilon$ more, up to the point at which $w_{1}^{S}=\underline{w}$. Second, small firms cannot offer a wage higher than $\underline{w}$. They have no own funds, and hence could only offer higher wages financed through external funds. But under the assumption that investors' claims are senior to wage claims, small firms cannot credibly offer $w_{1}^{S}>\underline{w}$. Nonetheless, both small firms and workers' respective surplus is 
positive, because they share the surplus of an idea, and investors only break even (because the capital market is competitive).

In what follows, we take $w^{S}=\underline{w}$ as given.

\section{A Screening and investment}

We show here that small firms optimally decide not to screen, while the large firm does, because it risks its own capital.

We consider a simple screening technology. Screening generates a signal that can take the value "good" $(s=g)$ or "bad" $(s=b)$. The probability of receiving a good signal when the idea is good is $p_{1} \equiv \operatorname{prob}(s=g \mid G)$, and the probability of receiving a good signal when the idea is bad is $p_{2} \equiv \operatorname{prob}(s=g \mid B)$. For the signal to be informative about the idea, we assume $p_{1}>p_{2}$. After observing the signal, firms update their beliefs on the quality of the idea. The probability that an idea is good after a good signal is:

$$
h_{1} \equiv h_{1}(g)=\frac{\alpha p_{1}}{\alpha p_{1}+(1-\alpha) p_{2}}
$$

and the probability that an idea is good after a bad signal is:

$$
h_{2} \equiv h_{2}(b)=\frac{\alpha\left(1-p_{1}\right)}{\alpha\left(1-p_{1}\right)+(1-\alpha)\left(1-p_{2}\right)} .
$$

As the signal is informative but involves errors, the following inequalities hold:

$$
0<h_{2}<\alpha<h_{1}<1
$$

Finally, to make the screening decision non-trivial, a bad signal must be sufficiently informative such that financing an idea after a bad signal has negative net present value: $h_{2}<\frac{I(1+r)+\underline{w}}{Y}$.

It is straightforward to show that the small firm does not screen the idea. A small firm's payoff of a successful idea is $\lambda\left[Y-D^{S}\right]$; the payoff if the idea fails is nil, because the firm has no own capital, pays no wage when it defaults and is protected by limited liability. The payoff of investing in the traditional technology is also nil, given that the firm cannot pay a wage below $\underline{w}$ and investors receive $(1+r) I$. Since because of limited liability $\lambda\left[Y-D^{S}\right] \geq 0$, small firms fund ideas even 
after a bad signal. Thus, they make the same decision regardless of the outcome of the screening process. As screening involves a cost $c$, small firms thus optimally decide to fund any idea without prior screening. Thus, $\widehat{\alpha}$ (the belief about the probability of a realized idea being good) equals $\alpha$, which, together with the assumption of a competitive capital market implies that $D^{S}=\frac{(1+r) I}{\alpha}$.

Incentives to screen and to realize ideas are different for the large firm. In order to determine under what condition it would want to screen, note first that independently from whether or not the firm invests in the safe technology or in the risky idea, it always has costs of $I+w_{1}^{L}$ (unless the idea is successfully realized).

If the firm decides to invest in the safe project, it receives revenues of:

$$
(1+r) I+\underline{w} .
$$

If the firms realizes the project of a worker, and the idea is successful, it receives a benefit of:

$$
\lambda(Y-(1+r) I)+(1+r) I .
$$

The first term is the firm's share of the total surplus of realizing a successful idea. The surplus is the gross revenue minus interest on and repayment of the large firm's own invested capital and is larger than in a small firm, because the large firm does not have to pay a premium on external funds. The second term represents exactly this reimbursement of invested capital plus the return of the risk-free technology.

Finally, if the idea fails, the firm receives nothing and loses its investment. Putting the above together, the firm's expected payoff if it realizes the idea without screening is: ${ }^{18}$

$$
\alpha[\lambda(Y-(1+r) I)+(1+r) I]-I-(1-\alpha) w_{1}^{L}
$$

because the idea is successful with probability $\alpha$ and the firm pays $w_{1}^{L}$ with probability $(1-\alpha)$ (as with probability $\alpha$ the worker receives her part of the idea's surplus $\left.(1-\lambda)(Y-(1+r) I) \geq w_{1}^{L}\right)$.

If the firm decides to screen, it gets an additional signal and updates its beliefs about the project. In order for screening to be relevant for the firm, it must be true that the firm realizes the

\footnotetext{
${ }^{18}$ Since the project has positive net present value the firm can always offer a sufficiently low wage $w_{1}^{L}$ that makes it desirable to realize the idea.
} 
project if the signal is good, while it invests in the safe technology if the signal is bad. Hence, the payoff associated with screening is:

$$
\begin{aligned}
\alpha p_{1}[\lambda(Y-(1+r) I)+ & (1+r) I]+ \\
& \left(\alpha\left(1-p_{1}\right)+(1-\alpha)\left(1-p_{2}\right)\right)[(1+r) I+\underline{w}]-I-\left(1-\alpha p_{1}\right) w_{1}^{L}-c .
\end{aligned}
$$

Notice that the first term is the probability of receiving a good signal.

Comparing the payoffs with and without screening, we find that screening is optimal if:

$$
\begin{aligned}
& {\left[\alpha\left(1-p_{1}\right)+(1-\alpha)\left(1-p_{2}\right)\right][(1+r) I+\underline{w}]>} \\
& \quad \alpha\left(1-p_{1}\right) *\left[\lambda(Y-(1+r) I)+(1+r) I+w_{1}^{L}\right]+c
\end{aligned}
$$

Dividing everything by the first term on the left hand side, using the definition of $h_{2}$ and combining it with the condition $h_{2}<\frac{I(1+r)+\underline{w}}{Y}$, the previous inequality can be rewritten as:

$$
(1+r) I+\underline{w}>\frac{I(1+r)+\underline{w}}{Y} *\left[\lambda(Y-(1+r) I)+(1+r) I+w_{1}^{L}\right]+\frac{c}{\alpha\left(1-p_{1}\right)+(1-\alpha)\left(1-p_{2}\right)} .
$$

This condition has a simple intuition. Screening is only useful if the firm were to implement a bad project in its absence. The left hand side represents the value of not making that error (the second-type error). The right hand side captures the value of the first-type error, as the firm implements less good projects and the cost of screening, multiplied by the inverse of the probability of receiving a bad signal, because it is only then that screening is useful for the firm.

Lemma 1 Small firms never screen and always fund workers' ideas. In contrast, if inequality (3) is satisfied, the large firm always screens and realizes ideas only after a good signal.

In what follows, to make the model non-trivial, we focus on an equilibrium in which inequality (3) is satisfied. This implies that the large and small firms have sufficiently different stakes at risk. Under this assumption, Lemma 1 implies that the large firm is more choosy in the decision to realize a project, and that the small firms accept both more good and more bad ideas. We provide some empirical support for Lemma 1 in Subsection VI.A. It is also noteworthy that Lemma 
1 is a common result in the corporate finance literature (see, for instance, Jensen and Meckling, 1976): Limited liability coupled with the use of external funds suboptimally increases risk-taking. The large firm's screening decision is optimal, because the cost of investment is internalized to a larger extent. Nonetheless, the lower probability of realizing the ideas of workers can reduce the large firm's profits in equilibrium, because it affects occupational choice. We show this in the next subsection.

\section{B Occupational choice of workers}

We here show that if ideas have ex ante positive net present value workers with an expected creativity above some $\phi^{*}$ prefer a job in a small firm, while workers with a creativity below $\phi^{*}$ prefer to work in the large firm.

Workers decide which firm to work for based on their compensation in different states of nature and their probability of having an idea. The following table summarizes probabilities of different states of nature and first-period compensation paid by the large and small firms.

\begin{tabular}{c|c|c|c|c} 
& $\begin{array}{c}\text { Idea } \\
\text { realized, succ. }\end{array}$ & $\begin{array}{c}\text { Idea } \\
\text { realized, fail. }\end{array}$ & $\begin{array}{c}\text { Idea } \\
\text { rejected }\end{array}$ & No idea \\
\hline Probability in large firm & $\phi \alpha p_{1}$ & $\phi(1-\alpha) p_{2}$ & $\phi\left[\begin{array}{c}\alpha\left(1-p_{1}\right)+ \\
(1-\alpha)\left(1-p_{2}\right)\end{array}\right]$ & $1-\phi$ \\
\hline Probability in small firm & $\phi \alpha$ & $\phi(1-\alpha)$ & 0 & $1-\phi$ \\
\hline Payoff in large firm & $(1-\lambda)(Y-I(1+r))$ & $w_{1}^{L}$ & $w_{1}^{L}$ & $w_{1}^{L}$ \\
\hline Payoff in small firm & $(1-\lambda)\left(Y-D^{S}\right)$ & 0 & - & $\underline{w}$
\end{tabular}

We define the indirect utility functions of different states of nature in the large $v s$ small firms below as a function of first and second period income. The last term in each parenthesis is second- 
period income, $\underline{w}$ for all workers:

$$
\begin{aligned}
U_{\text {trad }}^{L} & \equiv U^{*}\left(w_{1}^{L}, \underline{w}\right) \\
U_{\text {trad }}^{S} & \equiv U^{*}(\underline{w}, \underline{w}) \\
U_{\text {suc }}^{L} & \equiv U^{*}((1-\lambda)(Y-I(1+r)), \underline{w}) \\
U_{\text {suc }}^{S} & \equiv U^{*}\left((1-\lambda)\left(Y-D^{S}\right), \underline{w}\right) \\
U_{\text {fail }}^{L} & \equiv U^{*}\left(w_{1}^{L}, \underline{w}\right) \\
U_{\text {fail }}^{S} & \equiv U^{*}(0, \underline{w}) .
\end{aligned}
$$

Here we write $U_{f a i l}^{L}=U^{*}\left(w_{1}^{L}, \underline{w}\right)$, because we have assumed that the large firm has enough capital to always pay the fixed wage $w_{1}^{L}$. We analyze workers' occupational choice under the assumption that that $w_{1}^{L}>\underline{w}$. We prove in Proposition 1 that this condition must be satisfied if the set of workers in the large firm is non-empty and in Proposition 2 that offering $w_{1}^{L}>\underline{w}$ is indeed an optimal strategy for the large firm.

Given the above wage profile, workers borrow only if they are employed in a small firm, their idea is realized, and it fails. For this reason, all indirect utility function but $U_{f a i l}^{S}$ are unaffected by $B$, the maximum amount that may be borrowed at $t=4 ; U_{\text {fail }}^{S}$ is weakly increasing in $B$. As intertemporal utility maximization implies that workers want to consume the same amount in both periods of their life, we can conclude that they will want to borrow $\frac{w}{2}$. Therefore the borrowing constraint is binding in equilibrium only if $B<\frac{w}{2}$. We assume throughout the remaining of the paper that this inequality holds. We can now establish Proposition 1.

Proposition 1 If $p_{1}<\frac{\alpha U_{\text {suc }}^{S}+(1-\alpha) U_{\text {fail }}^{S}-U_{\text {trad }}^{L}}{\alpha\left(U_{\text {suc }}^{L}-U_{\text {trad }}^{L}\right)}$, the level of creativity at which a worker is indifferent between a large and a small firm is:

$$
\phi^{*}=\frac{U_{\text {trad }}^{L}-U_{\text {trad }}^{S}}{\alpha U_{\text {suc }}^{S}+(1-\alpha) U_{\text {fail }}^{S}-U_{\text {trad }}^{S}-\alpha p_{1}\left(U_{\text {suc }}^{L}-U_{\text {trad }}^{L}\right)} \in(0,1) .
$$

Workers with creativity $\phi \leq \phi^{*}$ choose the large firm, while workers with creativity $\phi>\phi^{*}$ choose small firms.

Occupational choice depends on the interplay of a number of effects. The evident advantages of 
the large firm consist in (a) a higher wage when the worker works in the traditional technology; (b) the insurance effect of receiving a wage even if an idea has failed. It will depend on the curvature of utility functions how important these effects are for workers. A more subtle effect is (c) the payoff from a successful idea is higher. Indeed, $U_{s u c}^{S}<U_{s u c}^{L}$, as higher financing costs reduce the surplus generated by the idea in a small firm compared to the large firm: $\left(Y-D^{S}\right)<(Y-I(1+r))$. Therefore, contingent on having a successful idea, the worker receives less in a small than in the large firm, an effect that, again, works against the small firm. There is only one benefit from working in a small firm: the probability of realizing a successful idea is larger. This is higher in small firms because screening involves first-type errors, which make large firms reject some ideas although they are good. The condition stated in Proposition 1 requires that this last effect is strong enough to make the most talented workers prefer small firms, as they care most about the realization of their idea. This is particularly likely if $p_{1}$ is small or $Y$ is large compared to $w^{L}$. In what follows, we assume that the condition in Proposition 1 is satisfied in equilibrium. ${ }^{19}$

Proposition 1 is similar to results in the literature on entrepreneurial choice (see, for instance Lucas, 1978), which has established that the most productive workers choose to become entrepreneurs (i.e., to realize their ideas). In our model, creativity is equivalent to expected productivity. Our results can be interpreted in a way that workers with higher expected productivity choose organizations where compensation is more strongly related to performance.

Proposition 1 also implies that for given wages higher expectation on the payoffs of ideas make relatively less creative workers more prone to work for small firms because the cost of first-type errors (i.e., good ideas erroneously rejected by a large firm) increases.

Corollary 1 For given wages, $\phi^{*}$ decreases in the expected payoff of ideas $(\alpha Y)$.

Proposition 1, together with the assumption that the creativity of workers is distributed uniformly on the support $[0,1]$, implies that the expected creativity of a worker employed in the large and small firms are, respectively:

\footnotetext{
${ }^{19}$ Together with inequality (4), this imply that $p_{1}$ must be included in an interval that depends on the parameters of the model. If $p_{1}>\frac{\alpha U_{s u c}^{S}+(1-\alpha) U_{\text {fail }}^{S}-U_{\text {trad }}^{L}}{\alpha\left(U_{s u c}^{L}-U_{\text {trad }}^{L}\right)}$ at $w_{1}^{L}=\underline{w}$, then even the most creative workers would prefer the large firm. Thus $w_{1}^{L}>\underline{w}$ would no longer be an equilibrium strategy for the large firm. Subsection VI.A provides evidence on firms' and workers' behavior suggesting that the condition in Proposition 1 and inequality (4) are likely to be satisfied in the reality.
} 


$$
\begin{aligned}
& E\left(\phi^{L}\right)=\frac{\phi^{*}}{2} ; \\
& E\left(\phi^{S}\right)=\frac{1+\phi^{*}}{2},
\end{aligned}
$$

where $\phi^{*}$ is defined as in Proposition 1.

\section{Wage determination}

Proposition 1 implies that when $w_{1}^{L}$ goes up, $\phi^{*}$ increases. ${ }^{20}$ Therefore, both the mass and expected productivity of the workers the large firm employs increase with $w_{1}^{L}$. Wages are thus used to attract creative workers. In other words, compensation is used as a tool to affect worker sorting, as in Lazear (1986).

Given $w_{1}^{S}=\underline{w}$, the large firm maximizes at $t=0$ :

$$
\max _{w_{1}^{L}} \phi^{*}\left[\left(1-E\left(\phi^{L}\right)\right)\left(r I+\underline{w}-w_{1}^{L}\right)+E\left(\phi^{L}\right) E\left(\pi_{1}^{L}\right)\right] .
$$

In (6), the first term in brackets represents the expected profit from a worker who does not generate an idea: the return from employing the firm's assets and the worker in the traditional technology minus the wage paid to the worker. The second term is the probability of attracting workers with ideas, multiplied by the firm's respective expected profit $E\left(\pi_{1}^{L}\right)$, which is net of the return of the traditional technology. The terms in brackets are multiplied by the mass of workers in the large firm, which gives total expected profit. Finally, $E\left(\pi_{1}^{L}\right)$ is the expected surplus prior to screening and contingent on realizing an idea after a good signal:

$$
\begin{aligned}
E\left(\pi_{1}^{L}\right)= & \alpha p_{1}\left[\lambda(Y-(1+r) I)+(1+r) I+w_{1}^{L}\right]+ \\
& \left(\alpha\left(1-p_{1}\right)+(1-\alpha)\left(1-p_{2}\right)\right)[(1+r) I+\underline{w}]-I-w_{1}^{L}-c .
\end{aligned}
$$

Equation (7) represents the sum of the expected gains when a good (bad) signal is observed, minus

\footnotetext{
${ }^{20}$ This derives from the fact that $\frac{d \phi^{*}}{d w_{1}^{L}}=\frac{U_{\text {trad }}^{L \prime}\left(\alpha U_{\text {suc }}^{S}+(1-\alpha) U_{\text {fail }}^{S}-U_{\text {trad }}^{S}-\alpha p_{1}\left(U_{\text {suc }}^{L}-U_{\text {trad }}^{S}\right)\right)}{\left(\alpha U_{\text {suc }}^{S}+(1-\alpha) U_{\text {fail }}^{S}-U_{\text {trad }}^{S}-\alpha p_{1}\left(U_{\text {suc }}^{L}-U_{\text {trad }}^{L}\right)\right)^{2}}>0$ if $p_{1}<$ $\frac{\alpha U_{s u c}^{S}+(1-\alpha) U_{\text {fail }}^{S}-U_{\text {trad }}^{L}}{\alpha\left(U_{\text {suc }}^{L}-U_{\text {trad }}^{L}\right)}$ as assumed in Proposition 1.
} 
the investment, the wage and the cost of screening. Note that Proposition 1 implies that the large firm has to offer $w_{1}^{L}>\underline{w}$ to attract a non-empty set of workers. Proposition 2 establishes when this is optimal.

Proposition 2 If the expected payoff of ideas is sufficiently high, the large firm offers a wage $w_{1}^{L}>\underline{w}$. Otherwise, it does not employ any workers and does not fund any ideas.

Proposition 2 implies that if the large firm decides to compete with small firms for creative workers, it must offer higher wages. The trade-off it faces is the following: by offering high wages, it attracts both a larger mass of workers and, on average, more talented workers. But a higher wage also implies that the per-capita profit of each worker employed in the traditional technology decreases. It is hence optimal for the large firm to compete with small firms if the expected surplus generated by new ideas is sufficiently large.

Finally, it is interesting to know that the expected number of ideas the large firm funds is: $x \equiv$ $E\left(\phi^{L}\right)\left(\alpha p_{1}+(1-\alpha) p_{2}\right)$. Therefore, our simplifying assumption that the large firm has enough funds to finance as many workers as it wants without failing can be relaxed to $A^{L} \geq x\left(I+w_{1}^{L}\right)$.

\section{Better access to credit}

Access to consumer credit increased dramatically in the second half of the eighties and during the nineties. As Guiso et al. (2001) and Sullivan (2002) show, it has become easier for U.S. households to borrow through unsecured debt, such as credit card debt, during unemployment spells. Proposition 3 shows that these developments in household access to financial markets are important for both occupational choice and firm profitability. In particular, we show that financial markets affect the willingness of workers to take on risks - through the level of the borrowing constraint $B$.

Proposition 3 If $B$ increases, the set of workers employed in small firms increases.

An increase in $B$ - through its effect on occupational choice - has other interesting effects which can be summarized as follows:

1. The large firm employs less creative workers and realizes fewer ideas. Thus, its profits per worker decrease. 
2. Small firms also employ on average less creative workers. Thus, small firms' profits per worker also decrease, because there are more workers without ideas who work with the traditional technology and make zero profits.

3. More ideas are realized in equilibrium, because small firms realize ideas with larger probability. This implies that there are both more second-type errors (more bad ideas of workers are financed) and less first-type errors (less good ideas are rejected).

4. The aggregate output of the affected sectors decreases. Small firms do not internalize the waste of investing assets in bad ideas and take excessive risk. This problem is less acute for the project selection of the large firm.

5. The expected utility of creative workers employed in small firms increases. They only risk their first-period wage when having their idea funded. Hence, provided that they can borrow a sufficient amount against their future income if their idea turns out to be a failure, they prefer to be employed in small firms. Also, the utility of workers employed in the large firm can increase, because $w_{1}^{L}$ may increase. Expected firm profits obviously decrease.

\section{Robustness and extensions}

We here discuss to what extent the assumptions of the model on contracts and screening can be relaxed. We also discuss implications of our analysis for organizational change and capital structure; we then look at different interpretations of what the large firm has at stake when deciding about workers' projects, and at unprofitable ideas.

\section{A Compensation contracts}

So far, we have restricted contracts to a fixed wage that is paid in all states of the world, except when the firm goes bankrupt or when a successful idea is realized. We have restricted the space of contracts in order to analyze the equilibrium under common job contracts which generally involve the negotiation of a wage and some expectations-that are not bargained upon- on the probability of being promoted and receiving a higher wage (the possibility of realizing one's own idea in our model). 
Here we discuss to what extent these assumptions could be relaxed. A framework of complete contracts would involve the possibility to stipulate one wage for each of the possible states of the world: (i) if the worker has no idea; (ii) if the worker suggests an idea that is not realized; (iii) if the idea is realized and fails; (iv) if the idea is realized with success. Compared to complete contracts, our assumptions imply a number of constraints for contracts: (a) for the large firm, compensation contracts in states $(\mathrm{i})=(\mathrm{ii})=($ iii); (b) for small firms, $(\mathrm{i})=($ ii); (c) for small firms, (iii) $=0$; (d) for both the large and the small firms, the worker/firm split of the surplus of a successful idea is exogenously given.

Constraint (d) may appear the most restrictive. We believe that it makes sense in the context of our model as the worker's idea is unknow at the contracting stage and firm and worker can bargain on the division of the surplus only in the interim period $(t=2)$. Formally, constraint (d) implies that there is a limit to which a worker can appropriate the surplus of their idea. This is the case if at the stage of implementation of the idea both the worker and the firm must be given incentives to provide complementary effort, which for simplicity we do not model. Note that if the large firm could offer a larger "success premium", its attractiveness among talented workers would increase. To see this, consider a given level of expected total compensation for the worker, that is, fixed wage plus the workers compensation when the idea is successful. The fixed wage provides insurance, which attracts talented workers, but as the same wage is paid to all workers, less talented workers receive a subsidy. Hence, the large firm can better target talented workers by reducing the fixed wage and paying a higher success premium. Allowing for a larger success premium changes the parameter range in which our results hold. It does, however, not change the results qualitatively. In our model, outside investors receive a larger share of the surplus than the large firm receives for its own funds. Thus, the surplus in the large firm is already higher than in the small firm. Relaxing constraint (d) would simply change the difference in worker payoffs between the large and small firms without changing the mechanics of the model, provided that the probability of realizing one's own idea is sufficiently larger in a small firm.

Constraint (c) can be relaxed by allowing for small firms to have some internal funds. We discuss the case of such firms with intermediate amounts of capital in Subsection D. Constraints (a) and (b) have in common that a worker with an idea is only compensated for it, when it is successfully realized. It does not seem very realistic that firms could make payments contingent 
on the occurrence of an idea that is not realized. However, even if one allowed for such payments, the logic of the model would stay intact. Consider a slight change in the large firm's wage scheme through which the worker receives a higher pay in case they have an idea, and to keep the total wage sum constant, reduce the payment workers receive when they have no idea. Such a scheme would be more attractive for talented workers. Small firms always realize workers' ideas thus making irrelevant compensation when ideas are not realized. Even if small firms rejected workers' ideas with positive probability, they could not increase their payment when an idea occurs but is not realized, because in equilibrium they cannot finance wages through external funds. Hence, the critical talent level at which workers move to small firms would increase, but the logic of the model stays intact, again provided that the probability of realizing ideas remains sufficiently larger in the small firms than in the large firm.

\section{B Screening}

We have assumed that firms cannot commit themselves to screen or not to screen. Rather they take the ex post optimal decision. Otherwise, the large firm could choose to commit itself not to screen in order to realize more risky projects and to be more competitive on the labor market. We believe, however, that our assumption makes sense. Screening is an internal decision of the firm. Investors cannot observe how the firm designs its screening process. Neither would workers be able to judge how the firm screens. Hence, it would be difficult to make contracts contingent on screening (this would imply some type of costly state verification to be carried out before implementation). However, while it may be quite difficult for a firm to commit contractually to a certain intensity of screening, a firm can engage in policies of organizational change to reduce the screening intensity. We discuss this further in the next subsection.

Finally, it is interesting that the large firm's equilibrium screening behavior makes redundant the assumption that a worker's idea can be realized only within the firm. Rather, this arises as an equilibrium outcome. The large firm does not realize a worker's idea after screening and observing a bad signal, because the expected payoff of realizing the idea is negative ex post. Hence, any idea that has been previously rejected by the large firm is known to have negative net present value, and as such would not find any financiers. The assumption could hence in principle be dropped. 


\section{Organizational change and capital structure}

An asset-intensive firm can react to the competition of small firms by spinning off units, that is, by creating low-capitalized separate legal entities. This allows the firm to commit itself to carry out less intensive screening as managers of spin-offs consider the capital provided by the headquarters as external funds. Hence, they are less conservative about realizing the workers' ideas. This implication - organizational change can be used to create incentives for risk-taking - is similar to the thrust of Aghion and Tirole (1997). They argue that by delegating authority, firms can commit themselves to realize more of their workers preferred projects (ideas). This increases their utility and hence relaxes workers' participation constraint. The mechanism we propose differs in two important ways from Aghion and Tirole. First, we focus on sorting of individuals with different level of creativity (adverse selection) and not on the incentives to exert effort (moral hazard). Second, we investigate the incentives of different firms to realize workers' ideas as a function of what firms have at stake.

An effect similar to the one of organizational change can be achieved using changes in capital structure: a large firm can distribute dividends (or buy back equity) and increase leverage. Indeed, there is evidence that this happened during the nineties (Economist, 2002). However, when new ideas are realized within the existing firms, their cash flows are mingled with the firm's other cash flows. Therefore, for large firms with many simultaneous projects it may not be optimal to choose a capital structure that allows to change the incentives with respect to one project but affects adversely the incentives with respect to other projects. For this reason, we believe that the implications for organizational change are more relevant.

Notice finally that the implications of our model are in line with the way innovation is promoted in sectors in which worker creativity is crucial for success. In biotechnology, for instance, innovation often takes place in small independent start-ups that have contractual ties to large asset-intensive firms in the pharmaceutical industry (Lerner and Merges, 1998). Biotechnological research involves the application of ideas within the organization, just as in our model. Our model highlights that firms pursuing a policy of decentralization in order to attract talented workers may take on too much risk and, ultimately, may default. 


\section{Intermediate degrees of capitalization}

In the model, we have taken a drastic simplification: there are only two types of firms. The large firm has sufficient internal funds to finance the idea internally and to commit itself to pay wages, even if ideas fail. Small firms have no internal funds. They must finance ideas with external funds and cannot pay wages when an idea fails. In a more realistic setting, one should consider that there are firms that have intermediate amounts of internal funds. There are two ways of making clear how this affects the mechanics and the main results of the model. One can increase the amount of funds of small firms, or decrease the funds of the large firm. These are two sides of the same coin that provide some intuition.

First, consider that there is still one large firm with abundant internal funds and allow for small firms to have some internal funds. Assume further that investors are only willing to provide the differential between what is needed to realize an idea and a firm's own funds. Then, as investors claim less, the surplus that small firms and workers can share when an idea is successful increases. This makes small firms more attractive compared to the large firm, and involves that $\phi^{*}$ increases. However, when the amount of internal funds further increases, there comes a point where small firms start screening their workers' ideas, as they have their own funds at stake. Then, small firms lose their only advantage compared to large firms and they would no longer attract the most creative workers.

This has cross-sectional implications: firms with intermediate amounts of capital would find it hard to attract talented workers when they compete with larger and smaller firms in the same labor market. It also has longitudinal implications. Over their life cycle, low-capitalized small firms that generate cash flow from the realization of good ideas accumulate assets. They may then lose the competitive edge in attracting creative workers. Conversely, unlucky larger firms may decumulate assets and gain in attractiveness.

Second, consider now that small firms have no internal funds. The large firm has enough funds to finance the idea, but not enough to commit paying the fixed wage $w^{L}$ when the idea fails. What can the large firm do with funds that exceed the amount needed to fund ideas? Within our contractual assumptions, it is impossible to stipulate a specific wage paid when ideas fail, but it makes sense to assume that workers would receive the remaining capital. This would provide them with some, albeit imperfect, insurance. In a nutshell, compared to a large firm with abundant 
capital, this large firm would be less attractive to talented workers, but it could still be preferred by some workers relative to the small firm.

\section{E Simultaneous projects}

So far, the only difference between small and large firms was whether and to what extent they used external funds. However, $A^{L}$ can be interpreted as the value of concurrent projects rather than as internal funds. Future cash flows generated by these projects increase the probability of being able to repay external financiers, which provides incentives that are very similar to the ones created by the use of internal funds.

To see this, assume that a large firm has no internal funds but is running another project that generates a positive safe cash flow $X$ at the end of the first period. If $X>(1+r) I+w^{L}$, the firm will be able to repay external financiers with certainty. Consequently, the programme for the optimal screening intensity is identical to the one of a firm that funds workers' ideas internally. Since all results of our model hinge on small and large firms' different incentives to screen, it follows that large firms may incur the same difficulties in attracting creative workers. A diversified firm with low probability of default internalizes fully the cost of investment and is as conservative as a firm that uses internal funds in the decision to realize workers' ideas. The evidence presented in Subsection VI.B further supports the view that diversification may cause a competitive disadvantage for firms that wish to attract creative workers.

\section{F Bad ideas}

The nineties have been characterized by an increase in the expected payoffs of ideas, which accompanied the high-tech bubble. In our model this is captured either through a higher probability of success $(\alpha)$ or through a higher output in case of success $(Y)$. So far we have argued that $\alpha Y$ was so large that $\alpha Y \geq(1+r) I+\underline{w}$. In this section we show that the equilibrium is dramatically different if ideas cannot cover the initial investment. Arguably, this may resemble the situation in the seventies but also recessions in some sectors where ideas are expected to be less profitable.

If $\alpha Y<(1+r) I$, small firms lose their comparative advantage in attracting workers and their ability to fund ideas is impaired. Screening is then necessary to identify ideas that are worth investing. Yet, small firms, which do not risk internal funds and do not expect to repay external 
financiers in case of default, would nonetheless have an incentive not to screen. As a consequence, the participation constraint of external financiers cannot be satisfied. Unless firms could commit to screen or investors could observe screening decisions, ideas could not be realized in small firms. ${ }^{21}$

Consequently, if ideas are a priori not profitable, the large firm has a competitive advantage in attracting creative workers. Offering a wage $w_{1}^{L}=\underline{w}$, it could attract all workers as the wage would be equal to the one offered by small firms but the large firm would also give the possibility of realizing innovative ideas. In equilibrium, the large firm, solving a profit maximization problem similar to the one described in Proposition 2, may find it optimal to employ only a subset of workers offering a wage $w_{1}^{L}<\underline{w}$. The most creative workers expecting to have an idea with higher probability will accept a wage discount and choose to work in large firm. Interestingly, to the extent that workers can anticipate consumption only if they expect a safe stream of income in the future, as often happens with consumer credit, liquidity constraints do not affect occupational choice.

This implies that if the expectations about ideas become more pessimistic, creative workers will spurn small firms, because they lack both internal and external funds to invest in innovation.

If one interprets employment in small firms as entrepreneurial activity, ${ }^{22}$ then, the model also predicts that entrepreneurial activity is procyclical. This is similar to what Rampini (2004) finds. The reason however is very different: in Rampini's model, during recessions, potential entrepreneurs have difficulties to fund risky projects because of agency problems. In our model, workers sort themselves differently into small or large firms when the expected payoff from ideas changes. This, in turn, affects how many ideas are realized in equilibrium because firms' incentives to screen differ. In this way, we can explain why an improvement in the expected payoffs of ideas is followed by an increase in firm defaults without relying on irrational or overoptimistic expectations.

Our findings have also implications for the type of innovation that is funded in large vs small firms. Creative workers in sectors were ideas have ex ante negative net present value should prefer to be employed in large firms, the only ones which being able to committ to screen are able to fund ideas.

\footnotetext{
${ }^{21}$ Then, specialized lenders, such as venture capitalists, who are able to observe (at least imperfectly) the screening intensity adopted within the firm, are necessary to fund innovative projects.

${ }^{22}$ Small firms do not screen; one can hence interpret the decision to work in a small firm as becoming self-employed (we do so in some of our regressions). In this case, the fraction $1-\lambda$ of the surplus from the idea received by the worker can be interpreted as a discount, which derives from not being embedded in an organization.
} 


\section{Existing empirical support}

In this section, we first present support for the result that large firms screen more intensively than small firms (Lemma 1), and how this affects the attitudes of workers concerning large vs small firms. Second, we briefly summarize what is known about the relationship between income risk and occupational choice.

\section{A Large firms vs small firms: screening and occupational choice}

Our model posits that differences in the willingness of firms to realize new ideas depend on what companies have at stake. This is in the spirit of Sah and Stiglitz (1988): when considering new projects, organizations require a minimum consensus level (equivalent to the intensity of screening), which depends on what the organization has at stake. Companies can risk internal funds, future cash flows from concurrent projects, but also reputation and other intangible assets such as their customer base. Naturally, large firms have more at stake than smaller and younger firms. Hence, they adopt more centralized and hierarchical structures, which are a way to submit new ideas to more intensive screening (Child, 1973).

There is some direct empirical evidence that what firms have at stake influences their willingness to realize workers' ideas. Harberg (1963) finds that in contrast to small firms, the industrial laboratories of large companies are only minor sources of inventions. Even research-minded companies "wallowing in large profits from previous projects" are reluctant to realize new ideas. Rather, they concentrate on improving old products, an activity that resembles the traditional technology in our model. In large industrial laboratories, the research director spends much effort in developing research programmes for the entire team, in which each worker is assigned a prearranged task. Innovative ideas are subject to careful screening, as they could jeopardize the company's profits from previous projects and its assets. Hence, Harberg argues, despite good salaries and security, elaborate facilities and technical support, the most creative scientists shy away from industrial laboratories.

Harberg's findings seem to fit well with more recent circumstances. For instance, the Wall Street Journal (2002) reports that science and engineering Ph.Ds at General Electric felt frustrated because they were spending too much time on routine tasks instead of pursuing broader ideas. 
General Electric is highly diversified and one of the largest companies in its sector. This supports the interpretation that employees are less able to pursue their ideas in companies that have more at risk. Zenger (1994) presents survey evidence that for the same reason, small firms attract superior talent for their R\&D personnel (when they succeed in attracting capital to fund innovation). He shows that "individuals with exceptional ability and skills" - the most creative workers in our model - seek the independence small firms offer, precisely because their abilities and skills are more likely to be rewarded with the successful realization of their ideas.

Large companies have reacted differently to the increased competition for talent that seems to have occurred through the nineties. A few of them, which considered innovation at the core of their business, like General Electric, have decentralized by breaking up units and creating spin-offs. Others maintained their centralized organization at the risk of attracting less creative workers.

In line with our theory, Rajan and Wulf (2003) find that during the nineties hierarchies have become flatter and employees have been conferred more freedom to choose what to work on. As predicted by our theory, this is mainly true for companies with less physical assets per employee (i.e., for companies with less at risk). The authors argue that organizational changes depend upon increasing competition for employees' talent. In the light of our model, this does not only depend on the ease of finding start-up capital, but also on the willingness to choose jobs with riskier income profile.

Some of the implications of our model on non-hierarchical organizations and innovative activity are similar to Aghion and Tirole (1997). In their paper, flatter hierarchies and employee empowerment increase the initiative of workers and may hence contribute to spur innovation. Beyond Aghion and Tirole (1997), our model implies that (i) more creative workers are more likely to choose flatter organizations, i.e., organizations where they are more likely to realize their ideas; (ii) firms that have less at stake (small firms) have stronger incentives to empower their employees.

Moreover, our model allows to generate novel predictions on the link between firm organization and corporate volatility. Rajan and Wulf (2003) find that companies where employees are granted more responsibility, have higher volatility of earnings. In our theory, this is a consequence of the organizational change implying the realization of more ideas. In this respect, our theory can explain the increase in firm level volatility during the nineties, especially in sectors with more research and development and higher use of external funds (Comin and Philippon, 2005). The mechanism of our 
model is also supported by the fact that firm level volatility is a good predictor of unemployment risk, and volatility and dispersion of wages (Comin and Philippon, 2005).

\section{B Income risk and occupational choice}

A number of papers are consistent with the link between income risk and occupational choice that we posit. Gruber (1997) provides evidence that unemployment is followed by a drop in consumption, which is larger for individuals with higher after-tax real wages. Fuchs-Schundeln and Schundeln (2004) provide closely related evidence; they show that more risk-averse individuals self-select in secure jobs. Gollier (2000) shows that liquidity constraints make individuals more risk averse, which is also in line with our argument. Guiso and Paiella (2001) show that individual risk aversion is positively related to liquidity constraints and that less risk averse individuals are more likely to be self-employed.

Moreover, occupational choice is known to be influenced by institutional factors that affect downside risk in a way similar to liquidity constraints. Fan and White (2003) and Berkowitz and White (2004), for instance, study the effect of U.S. bankruptcy exemptions that reduce downside risk in a way similar to relaxed liquidity constraints. Bankruptcy exemptions provide partial wealth insurance for risk-averse potential entrepreneurs. Empirically, in states with higher bankruptcy exemptions, access to credit for small firms and households is more difficult and small firms are more likely to be denied credit. Also, the loans that are given are smaller and interest rates are higher. Nonetheless, the probability of owning a business is higher when exemption levels are higher. This suggests that incentives for risk-taking, may be equally important as access to credit for start-ups in explaining entrepreneurial activity, and, more generally, for occupational choice. In the above papers, the channel is bankruptcy exemptions, in our model, it is relaxed liquidity constraints

Overall, the existing empirical evidence suggests that income risk matters for worker sorting. Arguably, an increase in the supply of consumer credit could explain workers' increased propensity to choose risky jobs. The next section carries out an econometric analysis of this implication of our theory. 


\section{Empirical evidence}

In our model, a relaxation in the borrowing constraint captures the linkage between improved insurance against downside risk and occupational choice. When liquidity constraints are relaxed, consumption can be smoothed better when an idea turns out to be bad. There is strong evidence that liquidity constraints for households have been relaxing over time in several countries (Jappelli and Pagano, 1994; Debelle, 2004). ${ }^{23}$ However, the link between liquidity constraints and changes in workers' attitudes over jobs has neither been established theoretically nor empirically. We just have anecdotal evidence about higher propensity to take risky jobs in the nineties, when downsides became less problematic (Cappelli, 1999; Malone 2003). The bulk of our empirical analysis (Subsection B) establishes this link in a systematic way, by using information about liquidity constraints as a proxy for downside risk. We also show that a proxy for the upside of risky ideas, which, throughout the nineties, may have increased because of innovation and the high-tech bubble, can indeed explain changes in workers' occupational choice over time.

\section{A Data and empirical strategy}

We use the "Survey of Consumer Finances (SCF)", a triennial survey of balance sheets, income data, and demographic characteristics of U.S. households, conducted by the Board of Governors of the Federal Reserves System since 1989. The latest edition of SCF we have access to is 2001. SCF is one of the primary data sources for research on entrepreneurship and small businesses (see, for instance, Wolken, 1998, Moskowitz and Vissing-Jorgensen, 2002).

SCF provides detailed information on employment of household members. In particular, we know the size of the firm that employs an individual, and whether an individual runs her own business. There are also several items on household access to consumer credit. We have information on credit card limits, the maximum amount that can be drawn on credit lines, and we know whether households were denied credit or were discouraged from borrowing.

Figure 1 and 2 plots the fraction of individuals working in small firms (defined as firms with

\footnotetext{
${ }^{23}$ Especially in the U.S. during the nineties, households have been able to increase their indebtedness. The U.S. household balances on unsecured loans, such as credit cards and overdraft provisions on checking accounts, have doubled in real terms between 1984 and 1999, and unsecured debt has helped households to smooth consumption during unemployment spells (Sullivan, 2002). In addition, increasing housing prices have allowed households to increase their mortgages, contributing to relaxed liquidity constraints.
} 
fewer than 100 employees), and the maximum amount that can be drawn on the household's credit cards and credit lines. The figures suggest a picture that is largely consistent with the stylized facts we described in the Introduction. Employment in small firms seems to have increased substantially from 1989 to 1992. Then it oscillated, possibly driven by different expectations on the business cycles and the expected payoff of new ideas. Such an explanation would be consistent with the fact that employment in small firms appears higher in 1998 - the peak of the high-tech bubble - than in 2001 (after the burst of the bubble) or in 1995 (when expectations about the payoffs of ideas were less inflated). The unused credit limit of the median household also increased in real terms during the sample period, suggesting a relaxation of liquidity constraints.

Descriptive statistics provide only limited support for our theory. Trends may depend on sample changes over time; surveyed households may differ in unobserved characteristics that affect their occupational choice and access to credit. Further, contrary to the implications of our model, individuals with riskier income profiles might have tighter liquidity constraints than average.

However, the host of information provided by SCF allows to develop an econometric test of our theory. In our empirical strategy, we use the fact that individuals differ not only in respect to their creativity (as the model assumes), but also in characteristics that affect their ability to receive consumer credit. Hence, we test the cross-sectional implication of our model for a given year. If our model is correct, other things equal, workers with less tight liquidity constraints should be more likely to sort into risky jobs. Put differently, we exploit individual heterogeneity in access to credit to test whether liquidity constraints are related to occupational choice. We do so at a given point in time, since SCF is a repeated cross-section dataset, and does not allow to follow the same household over time. The estimates we report are based on the $1998 \mathrm{SCF}$. The results are qualitatively similar for the other survey rounds.

We define the dummy variable risky occupation with value one, if a person is self-employed or employed in a small firm (with fewer than 100 employees), and zero otherwise. ${ }^{24}$ We estimate the probability that the head of household has such a risky occupation. Our main proxy for the ease of accessing credit is the unused part of credit card balances and lines of credit, defined as the maximum amount that can be drawn minus any amount that the household already owes. Such variables are often used in corporate finance as an inverse measure of financing constraints (see, for

\footnotetext{
${ }^{24}$ In our model small firms do not screen. Thus, for the empirical work we can treat similarly the decision to work in a small firm or becoming self-employed. We later also run robustness checks on this.
} 
instance, Petersen and Rajan, 1997 and Kaplan and Zingales, 1997). They are generally considered good proxies for the size of the buffer that the financial system can provide in bad times. However, the actual value of the variable depends on the demand for credit. For this reason, we also run our regressions using the limits on credit cards and lines of credit (without subtracting the amount that is actually owed). To the extent that they are supply-determined, as Sufi (2005) argues, they represent the actual willingness of intermediaries to provide credit.

Table 1 provides descriptive statistics for the main variables. Approximately, half of the individuals are either employed in small firms or are self-employed, the occupations that according to our model imply more income risk. As expected, the limit on credit cards is significantly smaller than the total amount that can be borrowed on credit cards and credit lines. Slightly less than 20 percent of the respondents declare that they were credit-constrained or were discouraged from borrowing. Notice that the average net wealth of households in the sample is very high (over 4 million U.S. dollars in 1998). The distribution is however highly skewed; the median household has a net wealth of less than 5,000 dollars in 1998 and net wealth (including pension assets and real estate) is less than 100,000 dollars for more than two thirds of the sample. Additionally, one quarter of the sample has negative net wealth.

\section{B Liquidity constraints and occupational choice}

The main hypothesis we test here is that, ceteris paribus, individuals with larger unused credit limits are more likely to be self-employed or to be employed in small firms. Table 2 shows the most important result. The proxy for access to credit is indeed associated with higher probability of holding such a risky occupation. The effect is not only statistically but also economically significant. A one-standard deviation increase in our proxy for liquidity constraints decreases the probability that an individual has a risky occupation by almost four percentage points. In the absence of our theory, it would be hardly conceivable that liquidity constraints matter for occupational choice in this way. Rather, one would expect the opposite, namely, that workers with safer jobs and more stable flows of income have easier access to credit, as banks consider them safer borrowers.

We carry out a series of robustness checks. First, an alternative explanation for our results could be that individuals belonging to households that are less likely to be liquidity constrained have easier access to start up capital. They would then be more likely to be self-employed, simply because 
they are able to make an initial investment. To evaluate whether the data support this alternative explanation, we control for household income, including the individual and the spouse income, and wealth, all of which represent alternative measures of access to capital (Table 2, regression 2). The spouse income also helps to control for an additional interesting channel through with the availability of insurance may affect occupational choice - the possibility of risk sharing within the household. We also include other individual characteristics that may affect occupational choice, like age, number of dependants, and whether the individual has a college degree. The regressions also control for the sector of activity, the type of task an individual performs on her job, and gender. Individuals who belong to richer households are indeed more likely to have risky occupations, but our previous findings remain intact: the higher a person's credit limit is, the higher the probability of having a risky occupation.

Interestingly, the estimates also suggest that workers with lower incomes are more likely to be employed in small firms. This is consistent with the implication of our model that small firms actually offer lower wages if they are able to fund new ideas. This result is in line with a large labor literature that has shown that larger firms usually pay higher wages (for an overview see Oi and Idson ,1999). One of the leading hypotheses is that the organization of the workplace and the selection of employees with unobservable characteristics are responsible for the positive relation between wages and employer size. Our empirical results are fully in line with this and the theory builds on related ideas. We also observe that older workers are more likely to be employed in small firms, which suggest that workers may move to small firms after having gained an experience at a larger company.

As a second robustness check, we exclude from our regression individuals who are self-employed. Thus, we can focus on the effect of access to credit on the choice between employment in large and small firms (Table 2, regression 3). Notice that the choice between large and small firms can never be driven by access to start-up capital as we here look at employees, not entrepreneurs. Yet, if liquidity constraints affect occupational choice, as we argue, the more liquidity-constrained workers should prefer a safer income profile. The data support this; individuals with larger unused credit limits are less likely to work in large firms. Since financial intermediaries should be more willing to lend to individuals with safer and highly verifiable salaries, such as large firms' employees, if anything, our regressions may underestimate the actual effect of liquidity constraints on occupational choice. 
Interestingly and in accordance to our conjecture that access to start capital should not affect the choice between small and large firms, wealth does not enter significantly in the regression.

We also consider alternative proxies for access to credit (Table 2, regressions 4 and 5): First, we consider only the credit card limit, which is more likely to be supply-determined, as credit card companies often mail free credit cards with high balances to households. Also, we use a dummy that takes value one if the household has been denied credit or has been discouraged from applying for a loan, in a way similar to Guiso, Jappelli and Terlizzese (1996) who analyze the effect of liquidity constraints on the decision to buy equity. In both cases, the estimates suggest that individuals with easier access to credit are more likely to be employed in small firms. Similar estimates obtain when we use the maximum amount that can be drawn on the households credit cards and credit lines (results omitted). Also, the results do not change much over different rounds of the survey. We do not report the estimates for different rounds here, but only the estimates obtained when pooling all survey rounds and including year dummies (Table 2, regression 6).

There are alternative mechanisms that could explain our results. One possibility is that individuals employed in small firms expect faster income growth. This would lead to reverse causality. According to the life cycle theory (Modigliani, 1986), it would then be optimal for them to apply for credit lines and higher credit card balances in order to anticipate consumption. We can investigate this alternative mechanism. The survey reports whether households expect their income to grow in the following year. In Table 3 (regression 1), we include a dummy variable that takes value one if households answers yes, and zero otherwise. Individuals working in small firms expect higher income growth, but this leaves the coefficient of the credit limit unchanged. Hence, the alternative mechanism can be discarded.

Another possibility is that individuals who work in small firms actively seek to obtain higher credit limits, because their income is more volatile. To check for this, we use a question in the survey that asks whether people "save for bad times". Household with higher income uncertainty may be more likely to save for the bad times and, at the same time, to attempt to increase their credit limits. The dummy variable income uncertainty takes value 1 if they answered yes, and zero otherwise. The estimates show that this variable is not statistically significant. Most importantly the coefficient of our variable of interest does not change much. In an alternative specification that we omit here, we proxy for income uncertainty by including a dummy variable equal to one if the 
households reports not to be able to give a good estimate of the following year income. Also in this case, the income uncertainty variable is not statistically significant and the coefficient of our variable of interest remains qualitatively the same.

Another concern could be that our sample includes very wealthy individuals, who are unlikely to ever be liquidity constrained because they can use their wealth to smooth consumption. If our results were driven by the richest individuals in our sample, we should be concerned that our different proxies for access to credit capture some omitted characteristics of the individual. Hence, in Table 3 (regression 3), we estimate the parameters excluding all individuals with more than 50,000 dollars wealth. ${ }^{25}$ Once again, the estimated coefficient of our variable of interest remains quite stable. Interestingly, when we exclude the wealthiest households, the coefficient of the spouse income becomes positive and almost statistically significant. This suggests that there may be insurance within the family besides insurance through financial markets, especially for poorer households. Hence, besides the relaxation of liquidity constraints, also the increasing proportion of two-earner households may have a role in explaining why job security has become less important.

Overall, we believe that our estimates, together with the fact that different proxies for access to credit yield qualitatively similar results, suggest that the credit limit affects occupational choice. To mitigate remaining concerns on endogeneity problems, however, we construct a more direct test of the mechanism of our model.

Our theoretical mechanism applies mainly for jobs where creativity is important. Individuals in management or R\&D gain more from realizing their ideas than others. We therefore run our regression for two different subsamples: workers with managerial or research-related jobs and workers with manual jobs. Access to credit should increase the probability of working in a small firm only in the first subsample. The estimates presented in Table 3 (regressions 4 and 5) suggest that this is indeed the case. Interestingly, the effect of liquidity constraints is more than double for managers and scientists with less than 1000 dollars wealth (estimates not reported), in other words for the ones who are more likely to value the ability to borrow in order to smooth consumption over time.

Finally, we use some of the time-series dimension of SCF to investigate whether, after controlling for wages, individuals become more prone to work in small firms when the expected payoff of the

\footnotetext{
${ }^{25}$ This is quite a small number if one considers that it includes real estate and pension assets, which an individual may not want to liquidate following a temporary income shock.
} 
ideas is larger. Both increases in $\alpha$ or $Y$ should increase the probability of employment in small firms. An increase in $\alpha$ has an additional, more subtle effect. It makes less likely that small firms default. Thus the importance of liquidity constraints should decrease, as less weight is put on the downside of ideas. In other words, individuals with relatively lower access to credit should choose to be employed in small firms as $\alpha$ increases. It is this testable effect that allows to distinguish our theory from others.

There are no precise data on the payoffs of ideas in our data set. Neither can we distinguish $Y$ from $\alpha$. However, we can use the yearly number of initial public offers (IPOs) as proxy. Arguably, years with a large number of IPOs are preceded by a lot of news on the good performance of entrepreneurial companies. This may lead individuals to revise upward their expectation on the upside of realizing their ideas. Using the yearly number of IPOs from Loughran and Ritter (2004), we run a regression similar to the previous ones, but we now use all survey rounds. We also include the yearly number of IPOs and an interaction term between the unused credit limit and the yearly number of IPOs, which is meant to capture the subtle effect of $\alpha$ on the importance of liquidity constraints for occupational choice.

The estimates presented in Table 3 (regression 6) show that an increase in yearly number of IPOs increases the probability of any individual being employed in a small firm. This alone is also consistent with a simple alternative theory - labor demand from small firms may be particularly strong during those years. However, the positive and significant sign of the interaction variable suggests that in years in which the payoff of ideas is expected to be higher, more individuals with relatively less access to credit are employed in small firms. In the absence of our theory, this is more difficult to explain. The alternative hypothesis based on labor demand of small firms could explain why more individuals work in small firms during those years, but could not explain why sorting of workers changes over time.

The estimated effect is not only statistically, but also economically significant: An increase in the number of IPOs from 344 to 566, respectively the median and the highest number of IPOs in our sample period, increase by 2.5 percentage points the probability that an individual with a credit limit of 7000 dollars (the median credit limit in the sample) is employed in a small firm. The effect is 3 percentage points if the individual has a credit limit of 66,000 (the highest decile in the sample). 


\section{Concluding remarks}

In our theory, financial market development eases household access to credit. When their liquidity constraints relax, workers change their attitude towards job and wage security in large firms. Rather, they seek riskier jobs in small firms, which allow them to realize their own ideas. As the upside of ideas is particularly important for talented workers, large firm lose while small firms gain in competing for talented workers. The theory points to a new channel through which access to credit matters, through the labor, rather than the capital market. Technological progress, which increases the payoffs of new ideas has similar effects.

Our theory has a number of implications two of which we would like to stress here. First, financial development and technological progress have dark sides: they may create excessive volatility and affect average firm profits negatively. Small firms are not necessarily good for the economy just because they are innovative. Since they do not have many assets or cash flows from other projects at risk, they recklessly fund new ideas and steal the most creative workers from large firms. Although large firms' cautious screening policies would be optimal, large firms may adopt policies to commit themselves to be less conservative. The creation of spin-offs and the increase in leverage may be seen as attempts to stop small firms from stealing the most creative workers, and to appropriate the profits from financing new ideas.

Second, the relative competitiveness of large $v s$ small firms may change along the business cycle. During booms, individuals find it easier to borrow, for instance by increasing their mortgage, and an increasing number of creative workers choose small firms. In contracting phases of the business cycle, household access to credit becomes more difficult, because real estate prices decrease or because households are too indebted. Then, a stable income becomes more important. This effect is reinforced because during recessions the ex ante expected payoff of realizing new ideas may be negative. Also, it becomes more difficult to find new jobs, and as a consequence, income losses after firm defaults are larger. Hence, jobs in large firms again become what they used to be before the boom: safe havens for workers.

The empirical investigation appears to corroborate our main proposition. Indeed, individuals that have less tight constraints are more likely to work in small firms. The finding is robust to the use of different proxies for liquidity constraints, to the inclusion of different control variables, and over time. Moreover, the effect is stronger for workers carrying out managerial or research tasks, 
arguably the ones for whom creativity is most important.

The logic of our model can also be applied in other contexts. Lenient bankruptcy laws, unemployment insurance, the ease to find new jobs affect workers' payoffs after firm default in a way very similar to the ease of liquidity constraints. The mechanism highlighted in our model suggests that these factors should spur risk taking in the labor market and ultimately innovation.

Finally, it should be noted that excessive risk-taking can also be optimal. For instance, if workers exert effort ex ante to generate profitable ideas, firms would want to commit themselves to realize ideas with high probability to increase incentives for workers. Whether or not excessive risk-taking spurs innovation and is beneficial for the overall economy is ultimately an empirical issue. We here see our contribution in pointing out a channel through which financial development may matter and in showing its implications on occupational choice, organizational change, and corporate volatility.

\section{References}

Aghion, P. and J. Tirole (1997), "Formal and Real Authority in Organization", Journal of Political Economy, vol 105, pp. 1-29.

Berkowitz, J. and M. J. White (2004), "Bankruptcy and Small Firms' Access to Credit", Rand Journal of Economics, vol. 35, pp. 69-84.

Cappelli, P. (1999), The New Deal at Work, Harvard Business School Press, Boston, Mass.

Caves, R. (1998), "Industrial Organization and New Findings on the Turnover and Mobility of Firms", Journal of Economic Literature, vol. 36, pp. 1947-82.

Child, J. (1973), "Predicting and Understanding Organization Structure", Administrative Science Quarterly, vol. 18, pp. 168-85.

Comin, D. and T. Philippon (2005), "The Rise in Firm-Level Volatility: Causes and Consequences" forthcoming NBER Macroeconomic Annual.

Crémer, J. (1995), "Arm's Length Relationships", Quarterly Journal of Economics, vol. 110, pp. 275-95. 
Day, J., P. Mang, A. Richter, J. Roberts (2001), "The Innovative Organization", The McKinsey Quarterly, no. 2.

Debelle, G. (2004), "Household Debt and the Macroeconomy", BIS Quarterly Review, March 2004, pp. 51-64.

Del Boca, D. and A. Lusardi (2003), "Credit Market Constraints and Labour Market Decisions", Labour Economics, vol. 10, pp. 681-703.

The Economist (2001), "Big is Beautiful Again", July 21, pp. 53-4.

The Economist (2002), "Dicing with Debt", January 26, pp. 23-5.

Fortin, N. M. (1995), "Allocation Inflexibilities, Female Labor Supply, and Housing Assets Accumulation: Are Women Working to Pay the Mortgage?", Journal of Labor Economics, vol. 13, pp. 524-557.

Fan, W. and White, M. J. (2003), "Personal Bankruptcy and the Level of Entrepreneurial Activity", Journal of Law and Economics, vol 46, pp. 543-67.

Fuchs-Schundeln, N. and M. Schundeln (2003), "Precautionary Savings and Self-Selection. Evidence from the German Reunification Experiment", mimeo Yale University.

Gollier, C. (2000), "What Does Theory Have to Say about Household Portfolios", in Guiso, L., M. Haliassos and T. Jappelli (2001), Household Portfolios, MIT Press.

Gromb, D. and Scharfstein (2002), "Entrepreneurship in Equilibrium", National Bureau of Economic Research Working Paper no. 9001.

Grossman, S. J. and O. D. Hart (1986), "The Costs and Benefits of Ownership: A Theory of Vertical and Lateral Integration", Journal of Political Economy, vol. 94, pp. 691-719.

Gruber, J. (1997), "The Consumption Smoothing Benefits of Unemployement Insurance", American Economic Review, vol. 87, pp. 192-205.

Guiso, L., M. Haliassos and T. Jappelli (2001), Household Portfolios, MIT Press. 
Guiso, L. T. Jappelli, and D. Terlizzese (1996), "Income Risk, Borrowing Constraints, and Portfolio Choice", American Economic Review, vol. 86, pp. 158-72.

Guiso, L. and M. Paiella (2001), "Risk Aversion, Wealth and Background Risk", Center for Economic Policy Research Working Paper no. 2728.

Harberg, D. (1963), "Invention in the Industrial Research Laboratory", Journal of Political Economy, vol. 71, pp. 95-115.

Hurst, E. and A. Lusardi (2003), "Liquidity Constraints, Household Wealth and Entrepreneurship", Journal of Political Economy, vol. 112, pp. 319-347.

International Social Survey Programme (1989), Work Orientations I, http://www.dataarchive.ac.uk/findingData/snDescription.asp?sn=2864.

International Social Survey Programme (1997), Work Orientations II, http://www.dataarchive.ac.uk/findingData/snDescription.asp?sn=4481.

Jappelli, T. and M. Pagano (1994), "Saving Growth, and Liquidity Constraints", Quarterly Journal of Economics, vol. 106, pp. 83-109.

Jensen, M. and W. Meckling (1976), "Theory of the Firm: Managerial Behavior, Agency Costs and Ownership Structure", Journal of Financial Economics, vol. 3, pp. 305-60.

Kaplan, S. L. and L. Zingales (1997), "Do Investment-Cash Flow Sensitivities Provide Useful Measures of Financing Constraints?", Quarterly Journal of Economics, vol. 112, pp. 169-215.

Laux, C. (2001), "Project-Specific External Financing and Headquarters' Monitoring Incentives", Journal of Law, Economics and Organization, vol. 17, pp. 397-412.

Lawler, E., S. Mohrman and G. Ledford (1995), Creating High Performance Organizations, San Francisco: Jossey Bass Publishers.

Lazear, E. (2001), "The Power of Incentives", American Economic Review, Papers and Proceedings, vol. 90, pp. 410-14.

Lazear, E. (1986), "Salaries and Piece Rates", Journal of Business, vol. 59, pp. 405-31. 
Lerner, J. and R. P. Merges (1998), "The Control of Technology Alliances: An Empirical Analysis of Biotechnology", Journal of Industrial Economics, pp. 125-55.

Loughran, T. and J. Ritter (2004), "Why Has IPO Underpricing

Changed Over Time?", Financial Management, vol. 33, pp. 5-37.

Lucas, R. E. (1978), "On the Size Distribution of Business Firms", Bell Journal of Economics, vol. 9 , pp. $508-23$.

Malone, T. W. (2003), Inventing the Organizations of the 21 ${ }^{\text {st }}$ Century, The MIT Press, Cambridge, Mass.

Michaels, E., H. Handfield-Jones and B. Axelrod (2001), The War for Talent, Harvard Business School Press, Boston, Mass.

Michelacci, C. and J. Suarez (2004), "Business Creation and the Stock Market", Review of Economic Studies, vol. 71, pp.459-81.

Modigliani, F. (1986), "Life Cycle, Individual Thrift, and the Wealth of Nations", American Economic Review, vol. 76, pp. 297-313.

Mohnen, P. and L.-H. Roeller (2005), "Complementarities in Innovation Policy", European Economic Review, vol. 49, pp. 1431-50.

Moskowitz, T. J. and A. Vissing-Jørgensen (2002), "The Private Equity Premium Puzzle", American Economic Review, vol. 92, pp. 745-78.

Oi, W. and T. Idson, "Firm size and wages", in Orley Ashenfelter and David Card (ed.), 1999. "Handbook of Labor Economics," Handbook of Labor Economics, Elsevier, edition 1, volume 3, number 3, March, chapter 33, pages 2165-2214.

Petersen, M. A. and R. Rajan (1994), "The Benefits of Firm-Creditor Relationships: Evidence from Small Business Data", Journal of Finance, vol. 49, pp. 3-37.

Pryor, F. (2001), "Will Most of Us Be Working for Giant Enterprises by 2028?", Journal of Economic Behavior and Organization, vol.44, pp. 363-82. 
Rajan, R. and L. Zingales (2001), "The Influence of the Financial Revolution on the Nature of Firms", American Economic Review Papers and Proceedings, vol. 92, pp. 206-11.

Rajan, R. and J. Wulf (2003), "The Flattening Firm: Evidence from Panel Data on the Changing Nature of Corporate Hierarchies", National Bureau of Economic Research Working Paper no. 9633.

Rampini, A. (2004), "Entrepreneurial Activity, Risk and the Business Cycle", Journal of Monetary Economics, vol. 51, pp. 555-73.

Rotemberg, J. and G. Saloner (2000), "Visionaries, Managers, and Strategic Direction", Rand Journal of Economics, vol. 31, pp. 693-716.

Sah, R. and J. Stiglitz (1988), "Committees, Hierarchies and Polyarchies", Economic Journal, vol. 98 , pp. $451-40$.

Scharfstein, D. and J. C. Stein (2000), "The Dark Side of Internal Capital Markets: Divisional Rent-Seeking and Inefficient Investment", Journal of Finance, vol. 55, pp. 2537-64.

Stein, J. C. (2002), "Information Production and Capital Allocation: Decentralized vs. Hierarchical Firms", Journal of Finance, vol. 1891-921.

Stum, D. L. (1998), "Five Ingredients for an Employee Retention Formula", HR Focus, vol. 75, p. 9.

Sufi, A. (2005), "Bank Lines of Credit in Corporate Finance: An Empirical Analysis", mimeo Chicago University.

Sullivan, J. X. (2002), "Borrowing During Unemployment: Unsecured Debt as a Safety Net", mimeo Northwestern University.

Valikangas, L., V. L. Magnotta and A. Fowler (2003), "Manage Innovation as a Corporate Capability", Chemical Engineering Progress.

Wall Street Journal (2002), "GE Goes Back to the Future", May 7.

Wolken, John D. (1998), "New Data Sources for Research on Small Business Finance", Journal of Banking and Finance, vol. 22, pp.1067-76. 
Zenger, T. R. (1994), "Explaining Organizational Diseconomies of Scale in R\&D: Agency Problems and the Allocation of Engineering Talent, Ideas, and Effort by Firm Size", Management Science, vol. 40, pp. 706-29.

Zingales, L. (2000), "In Search of New Foundations", Journal of Finance, vol. 55, pp. 1623-53. 


\section{A Appendix}

\section{A Proof of Proposition 1}

The cutoff level of creativity in Proposition 1 is determined by equating the expected utility from working in a large and in a small firm (see the payoff table):

$$
\begin{aligned}
& \phi\left[\alpha U_{\text {suc }}^{S}+(1-\alpha) U_{\text {fail }}^{S}\right]+(1-\phi) U_{\text {trad }}^{S}= \\
& \phi\left[\alpha p_{1} U_{\text {suc }}^{L}+(1-\alpha) p_{2} U_{\text {fail }}^{L}\right]+\left[1-\phi\left(\alpha p_{1}+(1-\alpha) p_{2}\right)\right] U_{\text {trad }}^{L}
\end{aligned}
$$

As $U_{\text {trad }}^{L}=U_{\text {fail }}^{L}$, this can be rewritten as:

$$
\phi\left[\left(\alpha U_{\text {suc }}^{S}+(1-\alpha) U_{\text {fail }}^{S}-U_{\text {trad }}^{S}\right)+\alpha p_{1}\left(U_{\text {trad }}^{L}-U_{\text {suc }}^{L}\right)\right]=U_{\text {trad }}^{L}-U_{\text {trad }}^{S},
$$

from which the equation in Proposition 1 follows. The term in the first set of parentheses of the left hand side in equation (8) is positive, the second term is negative; the right hand side is positive. Therefore if $U_{s u c}^{S}$ is too small and/or $p_{1}$ too large, $\phi^{*}$ is not defined and no worker chooses a small firm. A necessary condition for the set of workers who want to work in small firms to be non-empty is:

$$
\left(\alpha U_{\text {suc }}^{S}+(1-\alpha) U_{\text {fail }}^{S}-U_{\text {trad }}^{S}\right)+\alpha p_{1}\left(U_{\text {trad }}^{L}-U_{\text {suc }}^{L}\right)>U_{\text {trad }}^{L}-U_{\text {trad }}^{S},
$$

i.e., the benefits from working in a small firm must exceed the costs for the most creative worker

$(\phi=1)$. (9) implies $p_{1}<\frac{\alpha U_{\text {suc }}^{S}+(1-\alpha) U_{\text {fail }}^{S}-U_{\text {trad }}^{L}}{\alpha\left(U_{\text {suc }}^{L}-U_{\text {trad }}^{L}\right)}$. Under the assumption that the left hand side of the above expression is larger than the right hand side, it is obvious from equation (8) that the left hand side increases in $\phi$ faster than the right hand side. This implies that the expected utility from working in a small firm is larger than the expected utility from working in a large firm for all workers with creativity $\phi>\phi^{*}$.

Finally, note that $\phi^{*} \in[0,1]$ implies $w_{1}^{L}>\underline{w}$. The set of workers in the large firm is non-empty only if the utility from working in the large firm exceeds the utility in the small firm for the least creative worker $(\phi=0)$, which implies: $U_{\text {trad }}^{L}-U_{\text {trad }}^{S}>0$, and thus $w_{1}^{L}>\underline{w}$. 


\section{B Proof of Corollary 1}

Corrolary 1 simply follows from the fact that if $p_{1}<\frac{\alpha U_{s u c}^{S}+(1-\alpha) U_{\text {fail }}^{S}-U_{\text {trad }}^{L}}{\alpha\left(U_{s u c}^{L}-U_{\text {trad }}^{L}\right)}$, then:

$$
\begin{aligned}
\frac{d \phi^{*}}{d \alpha} & =-\phi^{*} \frac{U_{\text {suc }}^{S}-U_{\text {fail }}^{S}-p_{1}\left(U_{\text {suc }}^{L}-U_{\text {trad }}^{L}\right)}{\left(\alpha U_{\text {suc }}^{S}+(1-\alpha) U_{\text {fail }}^{S}-U_{\text {trad }}^{S}-\alpha p_{1}\left(U_{\text {suc }}^{L}-U_{\text {trad }}^{L}\right)\right)}<0 \text { and } \\
\frac{d \phi^{*}}{d Y} & =-\phi^{*} \frac{U_{\text {suc }}^{S \prime}-p_{1} U_{\text {suc }}^{L \prime}}{\left(\alpha U_{\text {suc }}^{S}+(1-\alpha) U_{\text {fail }}^{S}-U_{\text {trad }}^{S}-\alpha p_{1}\left(U_{\text {suc }}^{L}-U_{\text {trad }}^{L}\right)\right)}<0
\end{aligned}
$$

as $U_{\text {suc }}^{S \prime}>U_{\text {suc }}^{L \prime}$.

\section{Proof of Proposition 2}

By employing capital in the traditional technology, the large firm can always obtain a payoff of zero.

The large firm thus chooses to employ a subset of creative workers offering a wage $w_{1}^{L}>\underline{w}$ only if the maximum of program (6) is larger than zero. After simplifications, the first-order condition of program (6) with respect to $w_{1}^{L}$ can be written as:

$$
\begin{aligned}
\phi^{*}\left[-\left(1-E\left(\phi^{L}\right)\right)+\frac{d E\left(\phi^{L}\right)}{d w_{1}^{L}} E\left(\pi_{1}^{L}\right)+\right. & \left.E\left(\phi^{L}\right) \frac{d E\left(\pi_{1}^{L}\right)}{d w_{1}^{L}}\right] \\
& +\frac{d \phi^{*}}{d w_{1}^{L}}\left[\left(r I+\underline{w}-w_{1}^{L}\right)+E\left(\phi^{L}\right) E\left(\pi_{1}^{L}\right)\right]>0
\end{aligned}
$$

The first line represents the effect of an increase of $w_{1}^{L}$ on the per-capita profit of the firm, multiplied by the mass of workers who work in the large firm in equilibrium. This is negative. The second line represents the effect of an increase of $w_{1}^{L}$ on the mass of workers in the large firm, multiplied by the per-capita profit of the large firm. As this effect is positive for $w_{1}^{L}=\underline{w}$, the first-order condition can be satisfied with equality with levels of $w_{1}^{L}$ larger than $\underline{w}$.

If the first-order condition is satisfied with equality, the second-order condition is satisfied. To show this, considering that $E\left(\phi^{L}\right)=\frac{\phi^{*}}{2}$, the derivative of (10) with respect to $w_{1}^{L}$ can be written as: 


$$
\begin{aligned}
& \frac{d \phi^{*}}{d w_{1}^{L}}\left[-\left(1-\frac{\phi^{*}}{2}\right)+\frac{1}{2} \frac{d \phi^{*}}{d w_{1}^{L}} E\left(\pi_{1}^{L}\right)+\frac{\phi^{*}}{2} \frac{d E\left(\pi_{1}^{L}\right)}{d w_{1}^{L}}\right]+\frac{d^{2} \phi^{*}}{d\left(w_{1}^{L}\right)^{2}}\left[\left(r I+\underline{w}-w_{1}^{L}\right)+\frac{\phi^{*}}{2} E\left(\pi_{1}^{L}\right)\right]+ \\
& \frac{\phi^{*}}{2} \frac{d \phi^{*}}{d w_{1}^{L}}+\frac{\phi^{*}}{2} \frac{d^{2} \phi^{*}}{d\left(w_{1}^{L}\right)^{2}} E\left(\pi_{1}^{L}\right)+\frac{\phi^{*}}{2} \frac{d \phi^{*}}{d w_{1}^{L}} \frac{d E\left(\pi_{1}^{L}\right)}{d w_{1}^{L}}-\frac{d \phi^{*}}{d w_{1}^{L}}+\frac{1}{2}\left(\frac{d \phi^{*}}{d w_{1}^{L}}\right)^{2} E\left(\pi_{1}^{L}\right)+\frac{\phi^{*}}{2} \frac{d \phi^{*}}{d w_{1}^{L}} \frac{d E\left(\pi_{1}^{L}\right)}{d w_{1}^{L}}
\end{aligned}
$$

Here, $\frac{d E\left(\pi_{1}^{L}\right)}{d w_{1}^{L}}=-\left(1-\alpha p_{1}\right)<0$ and

$$
\frac{d^{2} \phi^{*}}{d\left(w_{1}^{L}\right)^{2}}=\frac{U_{\text {trad }}^{L \prime \prime}}{U_{\text {trad }}^{L \prime}} \frac{d \phi^{*}}{d w_{1}^{L}}-\frac{d \phi^{*}}{d w_{1}^{L}} \frac{U_{\text {trad }}^{L \prime}}{\left(\alpha U_{\text {suc }}^{S}+(1-\alpha) U_{\text {fail }}^{S}-U_{\text {trad }}^{S}-\alpha p_{1}\left(U_{\text {suc }}^{L}-U_{\text {trad }}^{L}\right)\right)}<0
$$

since $U_{\text {trad }}^{L \prime \prime}<0$.

Note that the first term of the second-order condition, $\frac{d \phi^{*}}{d w_{1}^{L}}\left[-\left(1-\frac{\phi^{*}}{2}\right)+\frac{1}{2} \frac{d \phi^{*}}{d w_{1}^{L}} E\left(\pi_{1}^{L}\right)+\frac{\phi^{*}}{2} \frac{d E\left(\pi_{1}^{L}\right)}{d w_{1}^{L}}\right]$, is necessarily negative if the first-order condition is satisfied with equality; the second term, $\frac{d^{2} \phi^{*}}{d\left(w_{1}^{L}\right)^{2}}\left[\left(r I+\underline{w}-w_{1}^{L}\right)+\frac{\phi^{*}}{2} E\left(\pi_{1}^{L}\right)\right]$, is also negative as $\left(r I+\underline{w}-w_{1}^{L}\right)+\frac{\phi^{*}}{2} E\left(\pi_{1}^{L}\right)>0$ if the expected profit per worker is positive; $\frac{\phi^{*}}{2} \frac{d^{2} \phi^{*}}{d\left(w_{1}^{L}\right)^{2}} E\left(\pi_{1}^{L}\right)$ and $\frac{\phi^{*}}{2} \frac{d \phi^{*}}{d w_{1}^{L}} \frac{d E\left(\pi_{1}^{L}\right)}{d w_{1}^{L}}$ are negative. Finally note that if the first-order condition is satisfied with equality, it must also be that $\frac{\phi^{*}}{2} \frac{d \phi^{*}}{d w_{1}^{L}} \frac{d E\left(\pi_{1}^{L}\right)}{d w_{1}^{L}}+$ $\frac{1}{2}\left(\frac{d \phi^{*}}{d w_{1}^{L}}\right)^{2} E\left(\pi_{1}^{L}\right)+\frac{\phi^{*}}{2} \frac{d \phi^{*}}{d w_{1}^{L}}-\frac{d \phi^{*}}{d w_{1}^{L}}=$

$=\frac{d \phi^{*}}{d w_{1}^{L}}\left[-\left(1-E\left(\phi^{L}\right)\right)+\frac{d E\left(\phi^{L}\right)}{d w_{1}^{L}} E\left(\pi_{1}^{L}\right)+E\left(\phi^{L}\right) \frac{d E\left(\pi_{1}^{L}\right)}{d w_{1}^{L}}\right]<0$.

This proves that the second-order condition is satisfied (as the second-order derivative is negative) if the first order condition is satisfied.

Note that if the first-order condition is always positive, the large firm offers a wage $w_{1}^{L}$ such that $\phi^{*}=1$. Similarly, if the first-order condition is not satisfied for $w_{1}^{L}=0, \phi^{*}=0$. Hence, if both the large firm and small firms employ non-empty sets of workers, the first-order condition must be satisfied with equality.

\section{Proof of Proposition 3}

As pointed out in Subsection III.B, the borrowing constraint is relevant only for workers in small firms in case an idea fails if $B<\frac{w}{2}$. Workers would then like to borrow to smooth their consumption, but they encounter a binding borrowing constraint. Hence, when $B$ increases to $B^{\prime}, U_{\text {fail }}^{S}$ increases. 
This implies that $\frac{d \phi^{*}}{d B}=-\frac{\phi^{*}(1-\alpha) U_{\text {fail }}^{S \prime}}{\left(\alpha U_{\text {suc }}^{S}+(1-\alpha) U_{f a i l}^{S}-U_{\text {trad }}^{S}-\alpha p_{1}\left(U_{\text {suc }}^{L}-U_{\text {trad }}^{L}\right)\right)}<0$. Hence, $\phi^{*}$ decreases, and for given wages, more workers want to be employed in small firms.

The wage small firms pay does not change, as it is pinned down by competition among firms and their lack of capital. By contradiction, assume that after the increase in $B$, the large firm would increase wages such that the set of workers it employs is larger $\left(\phi^{* \prime}>\phi^{*}\right)$. This would imply $w_{1}^{L \prime}>w_{1}^{L}$.

$\phi^{* \prime}$ is the optimal mass of worker to employ in equilibrium if

$$
\frac{\phi^{* \prime}}{2} E\left(\pi_{1}^{L}\left(B^{\prime}\right)\right)+\left(1-\frac{\phi^{* \prime}}{2}\right)\left(r I+\underline{w}-w_{1}^{L}\left(B^{\prime}\right)\right) \geq \frac{\phi^{*}}{2} E\left(\pi_{1}^{L}\left(B^{\prime}\right)\right)+\left(1-\frac{\phi^{*}}{2}\right)\left(r I+\underline{w}-w_{1}^{L}\left(B^{\prime}\right)\right) .
$$

Here, $w_{1}^{L}\left(B^{\prime}\right)$ is the wage, and $\pi_{1}^{L}\left(B^{\prime}\right)$ the level of expected profits per idea that is funded, when the level of liquidity constraint is $B^{\prime}$ and the mass of workers employed in a large firm is $\phi^{* \prime}$.

Similarly, when the liquidity constraint is $B$, profit maximization implies

$$
\frac{\phi^{*}}{2} E\left(\pi_{1}^{L}(B)\right)+\left(1-\frac{\phi^{*}}{2}\right)\left(r I+\underline{w}-w_{1}^{L}(B)\right) \geq \frac{\phi^{* \prime}}{2} E\left(\pi_{1}^{L}(B)\right)+\left(1-\frac{\phi^{* \prime}}{2}\right)\left(r I+\underline{w}-w_{1}^{L}(B)\right) .
$$

At $B<B^{\prime}$, the firm can employ a given mass of workers at a lower wage as $\frac{d \phi^{*}}{d B}<0$.This implies that

$$
\frac{\phi^{* \prime}}{2} E\left(\pi_{1}^{L}(B)\right)+\left(1-\frac{\phi^{* \prime}}{2}\right)\left(r I+\underline{w}-w_{1}^{L}(B)\right)>\frac{\phi^{* \prime}}{2} E\left(\pi_{1}^{L}\left(B^{\prime}\right)\right)+\left(1-\frac{\phi^{* \prime}}{2}\right)\left(r I+\underline{w}-w_{1}^{L}\left(B^{\prime}\right)\right),
$$

which leads to a contradiction.

Hence if $B^{\prime}>B, \phi^{* \prime}<\phi^{*}$. 
Table 1

\section{Descriptive statistics}

Panel A. This Table presents mean and standard deviation for the main variables used in the analysis. All survey rounds include the 1989, 1992, 1995, 1998, and 2001 rounds of the Survey of Consumer Finances (SCF). Only head of households who are employed at the time of the survey are included. Risky occupation is a dummy variable that takes value equal to 1 if the head of the household runs his own business or is employed in a firm with fewer than 100 employees and zero otherwise. Employed in small firms is a dummy variable that takes value equal to 1 if the head of the household is employed in a firm with fewer than 100 employees and zero otherwise (observations regarding individuals who run their own business are excluded). Credit limit is the unused part of the credit limit of all credit lines and credit cards of the household in thousands USD. Credit card limit is the unused part of the credit limit of all credit cards of the household in thousands USD. Credit constraint is a dummy variable that takes value 1 if the household has been denied credit or did not apply for a loan because anticipated to be denied credit and zero otherwise. Own income is the income of the head of the household in thousands USD. Spouse income is the income of the spouse in thousands USD. Household wealth has been computed as the sum of all financial and real assets of the household net of any liabilities and includes pension assets; is is expressed in thousands USD. Age is the age of the head of the household. Number of dependants is the number of members of the household who are financially dependent. College degree is a dummy variable that takes value 1 if the head of the household has a college degree and zero otherwise. Expectation of income growth is a dummy variable that takes value 1 if the household expects the income to grow during the following year and equal to zero otherwise. Income uncertainty is a variable that takes value 1 if the household declares to save for the bad times and zero otherwise. Yearly IPOs is the number of IPOs during the year.

\begin{tabular}{|c|c|c|c|c|c|c|}
\hline & \multicolumn{2}{|c|}{1998 sample } & \multicolumn{3}{|c|}{ All survey rounds } & \multirow[b]{2}{*}{$\begin{array}{r}\text { Standard } \\
\text { Deviation }\end{array}$} \\
\hline & No. obs. & Mean & $\begin{array}{r}\text { Standard } \\
\text { Deviation }\end{array}$ & No. obs. & Mean & \\
\hline Risky occupation & 14910 & 0.56 & 0.49 & 58644 & 0.44 & 0.497 \\
\hline Employed in small firms & 14091 & 0.53 & 0.49 & 52140 & 0.37 & 0.484 \\
\hline Credit limit & 14910 & 77.76 & 1066.90 & 58644 & 70.20 & 1160 \\
\hline Credit card limit & 14910 & 19.10 & 35.04 & 58644 & 17.74 & 4920 \\
\hline Credit constraint & 14910 & 0.19 & 0.39 & 58644 & 0.19 & 0.39 \\
\hline Own income & 14910 & 62.43 & 225.31 & 58644 & 73.07 & 701.38 \\
\hline Spouse income & 14910 & 9.03 & 26.36 & 58644 & 9.63 & 41.85 \\
\hline Household wealth & 14910 & 4615.60 & 23100 & 58644 & 3785.91 & 24000 \\
\hline Age & 14910 & 44.90 & 12.80 & 58619 & 44.97 & 12.88 \\
\hline Number of dependants & 14910 & 1.79 & 1.41 & 58644 & 1.54 & 1.33 \\
\hline College degree & 14910 & 0.50 & 0.50 & 58644 & 0.51 & 0.50 \\
\hline Expectation of income growth & 14910 & 0.33 & 0.47 & 30704 & 0.16 & 0.37 \\
\hline Income uncertainty & 14910 & 0.31 & 0.46 & 58644 & 0.55 & 0.50 \\
\hline Yearly IPOs & 14910 & 602 & 0 & 58644 & 517.63 & 101.82 \\
\hline
\end{tabular}


Panel B. This table presents the correlation matrix of the main variables as defined in Panel A. All survey rounds have been used to compute the correlation coefficients.

\begin{tabular}{|c|c|c|c|c|c|c|c|c|c|c|c|c|c|}
\hline & $\begin{array}{c}\text { Risky } \\
\text { occupation }\end{array}$ & $\begin{array}{c}\text { Employed } \\
\text { in small } \\
\text { firms }\end{array}$ & Credit limit & $\begin{array}{c}\text { Credit card } \\
\text { limit }\end{array}$ & $\begin{array}{c}\text { Credit } \\
\text { constraint } \\
\end{array}$ & $\begin{array}{c}\text { Own } \\
\text { income }\end{array}$ & $\begin{array}{l}\text { Spouse } \\
\text { income }\end{array}$ & $\begin{array}{c}\text { Household } \\
\text { wealth }\end{array}$ & Age & $\begin{array}{l}\text { Number of } \\
\text { dependants }\end{array}$ & $\begin{array}{l}\text { College } \\
\text { degree }\end{array}$ & $\begin{array}{l}\text { Expectation } \\
\text { of income } \\
\text { growth }\end{array}$ & $\begin{array}{c}\text { Income } \\
\text { uncertainty }\end{array}$ \\
\hline Risky occupation & 1 & & & & & & & & & & & & \\
\hline Employed in small firms & 0.7502 & 1 & . & & & & & & & & & & \\
\hline Credit limit & 0.0598 & 0.0382 & 1 & & & & & & & & & & \\
\hline Credit card limit & 0.0272 & 0.0121 & 0.3514 & 1 & & & & & & & & & \\
\hline Credit constraint & -0.1168 & -0.0539 & -0.0367 & -0.0375 & 1 & & & & & & & & \\
\hline Own income & -0.025 & -0.0354 & 0.0217 & 0.0394 & -0.0285 & 1 & & & & & & & \\
\hline Spouse income & 0.0037 & -0.0075 & 0.3096 & 0.8981 & -0.0271 & 0.0059 & 1 & & & & & & \\
\hline Household wealth & 0.0712 & 0.0485 & 0.1344 & 0.1003 & -0.0471 & 0.1177 & 0.0886 & 1 & & & & & \\
\hline Age & 0.3066 & 0.2161 & 0.0602 & 0.0473 & -0.2573 & 0.0387 & 0.0117 & 0.115 & 1 & & & & \\
\hline Number of dependants & 0.0318 & 0.0161 & -0.0064 & 0.0173 & -0.0039 & 0.0249 & 0.0326 & 0.0108 & -0.0963 & 1 & & & \\
\hline College degree & 0.1472 & 0.0394 & 0.0516 & 0.0515 & -0.1771 & 0.0629 & 0.0469 & 0.0753 & 0.1481 & 0.0075 & 1 & & \\
\hline Expectation of income growth & -0.0248 & -0.0056 & -0.01 & -0.0165 & 0.1171 & -0.0127 & -0.0119 & -0.014 & -0.1397 & 0.0218 & -0.0377 & 1 & \\
\hline Income uncertainty & 0.0367 & 0.0722 & 0.0056 & -0.0025 & 0.0732 & -0.01 & -0.0107 & 0.0061 & -0.0502 & -0.0332 & -0.077 & -0.0331 & 1 \\
\hline
\end{tabular}




\section{Table 2}

\section{Access to credit and occupational choice}

This table links the occupation of the head of the household to measures of access to credit and control variables. Specification (1)-(5) include only observation relative to the 1998 round of the survey. Specification (6) includes the 1989, 1992, 1995, 1998, and 2001 rounds. All variables are defined in Table 1. The following additional dummy variables have been included in the equations, but their coefficients are not reported: A dummy that takes value 1 if the head of the household is a female and zero otherwise, six dummies variables concerning the task of the head of the household in his (her) occupation, seven dummies concerning the sector of occupation of the head of the household. Additionally, in specification (6), four year dummies have been included. All equations have been estimated using a probit model and marginal effects and tstatistics are reported. Standard errors are corrected for heteroskedasticity.

\begin{tabular}{|c|c|c|c|c|c|c|c|c|c|c|c|c|}
\hline & \multicolumn{2}{|c|}{$\begin{array}{l}\text { Risky occupation } \\
(1) \\
\end{array}$} & \multicolumn{2}{|c|}{$\begin{array}{c}\text { Risky occupation } \\
(2)\end{array}$} & \multicolumn{2}{|c|}{$\begin{array}{c}\text { Small vs. large firms } \\
(3)\end{array}$} & \multicolumn{2}{|c|}{$\begin{array}{c}\text { Small vs. large firms } \\
(4)\end{array}$} & \multicolumn{2}{|c|}{$\begin{array}{c}\text { Small vs. large firms } \\
(5)\end{array}$} & \multicolumn{2}{|c|}{$\begin{array}{c}\text { Small vs. large firms } \\
(6)\end{array}$} \\
\hline & & & & & & & & & & & All survey ro & unds \\
\hline & Coefficient & -stat & Coefficient & T-stat & Coefficient & T-stat & Coefficient & T-stat & Coefficient & T-stat & Coefficient & T-stat \\
\hline Credit limit & 0.00033 & 4.2 & 0.0001 & 2.36 & 0.00008 & 2.41 & & & & & 0.000025 & 4.13 \\
\hline Credit card limit & & & & & & & 0.000077 & 3.68 & & & & \\
\hline Credit constraint & & & & & & & & & -0.00495 & -1.94 & & \\
\hline Own income & & & -0.020819 & -19.17 & -0.021105 & -18.85 & -0.021146 & -18.86 & -0.00472 & -19.9 & -0.0306 & -41.55 \\
\hline Spouse income & & & 0.0001 & -0.68 & -0.00011 & -0.61 & -0.00014 & -0.81 & 0.0000165 & 0.41 & -0.000088 & -1.31 \\
\hline Household wealth & & & 0.0000013 & 3.87 & 0.00000002 & 0.70 & 0.00000002 & 0.74 & 0.00000001 & 1.10 & 0.000000001 & 0.38 \\
\hline Age & & & 0.0074008 & 19.09 & 0.0068943 & 17.51 & 0.0066545 & 16.66 & 0.00167 & 20.07 & 0.00587 & 30.53 \\
\hline Number of dependants & & & 0.0077916 & 2.39 & 0.0073407 & 2.19 & 0.0068628 & 2.04 & 0.001636 & 2.19 & 0.006665 & 3.55 \\
\hline College degree & & & -0.027905 & -2.26 & -0.03686 & -2.92 & -0.042343 & -3.31 & -0.006999 & -2.52 & -0.048218 & -7.61 \\
\hline
\end{tabular}

\begin{tabular}{llrrrr} 
Obs. & 14910 & 14910 & 14091 & 14091 & 14091 \\
Pseudo R-squared & 0.0072 & 0.1534 & 0.1417 & 0.1423 & 0.1409 \\
\hline
\end{tabular}




\section{Table 3}

\section{Robustness analysis}

This table links the occupation of the head of the household to measures of access to credit and control variables. Specification (1)-(5) include only observation relative to the 1998 round of the survey. Specification (6) includes survey rounds 1989-2001. Specification (4) includes only observations relative to heads of the household who have managerial or research related jobs (managers and scientists). Specification (5) includes only observations relative to heads of the household who are employed as armed force, manual workers, drivers or farmers (manual workers). All variables are defined in Table 1 . The following additional dummy variables have been included in the equations, but their coefficients are not reported: A dummy that takes value 1 if the head of the household is a female and zero otherwise, six dummies variables concerning the task of the head of the household in his (her) occupation, seven dummies concerning the sector of occupation of the head of the household. All equations but equation (6) have been estimated using a probit model and marginal effects and t-statistics are reported. Equation (6) has been estimated by ordinary least squared to be able to directly interpret the interaction term. Standard errors are corrected for heteroskedasticity.

\begin{tabular}{|c|c|c|c|c|c|c|c|c|c|c|c|c|}
\hline & \multirow{2}{*}{\multicolumn{2}{|c|}{$\frac{\text { Small vs. large firms }}{(1)}$}} & \multirow{2}{*}{\multicolumn{2}{|c|}{ Small vs. large firms }} & \multirow{2}{*}{\multicolumn{2}{|c|}{$\begin{array}{c}\text { Small vs. large firms } \\
(3) \\
\end{array}$}} & \multicolumn{2}{|c|}{ Small vs. large firms } & \multicolumn{2}{|c|}{ Small vs. large firms } & \multicolumn{2}{|c|}{ Small vs. large firms } \\
\hline & & & & & & & (4) & & (5) & & $(6)$ & \\
\hline & \multirow[b]{2}{*}{ Coefficient } & \multirow[b]{2}{*}{ T-stat } & \multirow[b]{2}{*}{ Coefficient } & \multirow[b]{2}{*}{ T-stat } & \multicolumn{2}{|c|}{ Wealth $<50000$} & \multicolumn{2}{|c|}{ Managers and scientists } & \multicolumn{2}{|c|}{ Manual workers } & \multicolumn{2}{|c|}{ All survey rounds } \\
\hline & & & & & Coefficient & T-stat & Coefficient & T-stat & Coefficient & T-stat & Coefficient & T-stat \\
\hline Credit limit & 0.00001 & 2.34 & 0.00001 & 2.41 & 0.0005 & 2.64 & 0.00002 & 3.88 & -0.000059 & -1.6 & 0.000001 & 1.83 \\
\hline Credit limit *Yearly IPOs & & & & & & & & & & & 0.000001 & 2.67 \\
\hline Own income & -0.021016 & -18.77 & -0.02108 & -18.83 & -0.0023 & -7.96 & -0.042243 & -13.31 & -9.96 & -7.03 & -0.000217 & -4.16 \\
\hline Spouse income & -0.00014 & -0.79 & -0.00011 & -0.6 & 0.00058 & 1.58 & -0.000085 & -0.46 & 0.00059 & 1 & -0.000045 & -0.7 \\
\hline Household wealth & 0.0000002 & 0.63 & 0.0000002 & 0.68 & -0.00046 & -7.77 & -0.00000002 & -0.09 & 0.00024 & 5.17 & 0.0000008 & 2.49 \\
\hline Age & 0.0072151 & 18.01 & 0.006895 & 17.51 & 0.0048956 & 10.06 & 0.01 & 15.53 & 0.0021285 & 2.84 & 0.007293 & 33.26 \\
\hline Number of dependants & 0.0079355 & 2.36 & 0.007368 & 2.19 & 0.0039882 & 1 & 0.0140846 & 2.77 & -0.00082 & -0.14 & 0.010199 & 4.57 \\
\hline College degree & -0.036914 & -2.92 & -0.037042 & -2.93 & -0.029381 & -1.97 & & & & & -0.0151868 & -2.08 \\
\hline Expectation of income growth & 0.0691754 & 5.37 & & & & & & & & & & \\
\hline Income uncertainty & & & 0.006495 & 0.66 & & & & & & & & \\
\hline Number of IPOs during the pre & evious year & & & & & & & & & & 0.0000908 & 6.71 \\
\hline Obs. & & 14091 & & 14091 & & 9199 & & 6691 & & 4232 & & 52120 \\
\hline Pseudo R-squared & & 0.1433 & & 0.1418 & & 0.13 & & 0.1596 & & 0.2257 & & 0.1951 \\
\hline
\end{tabular}


Figure 1

Employment in small firms

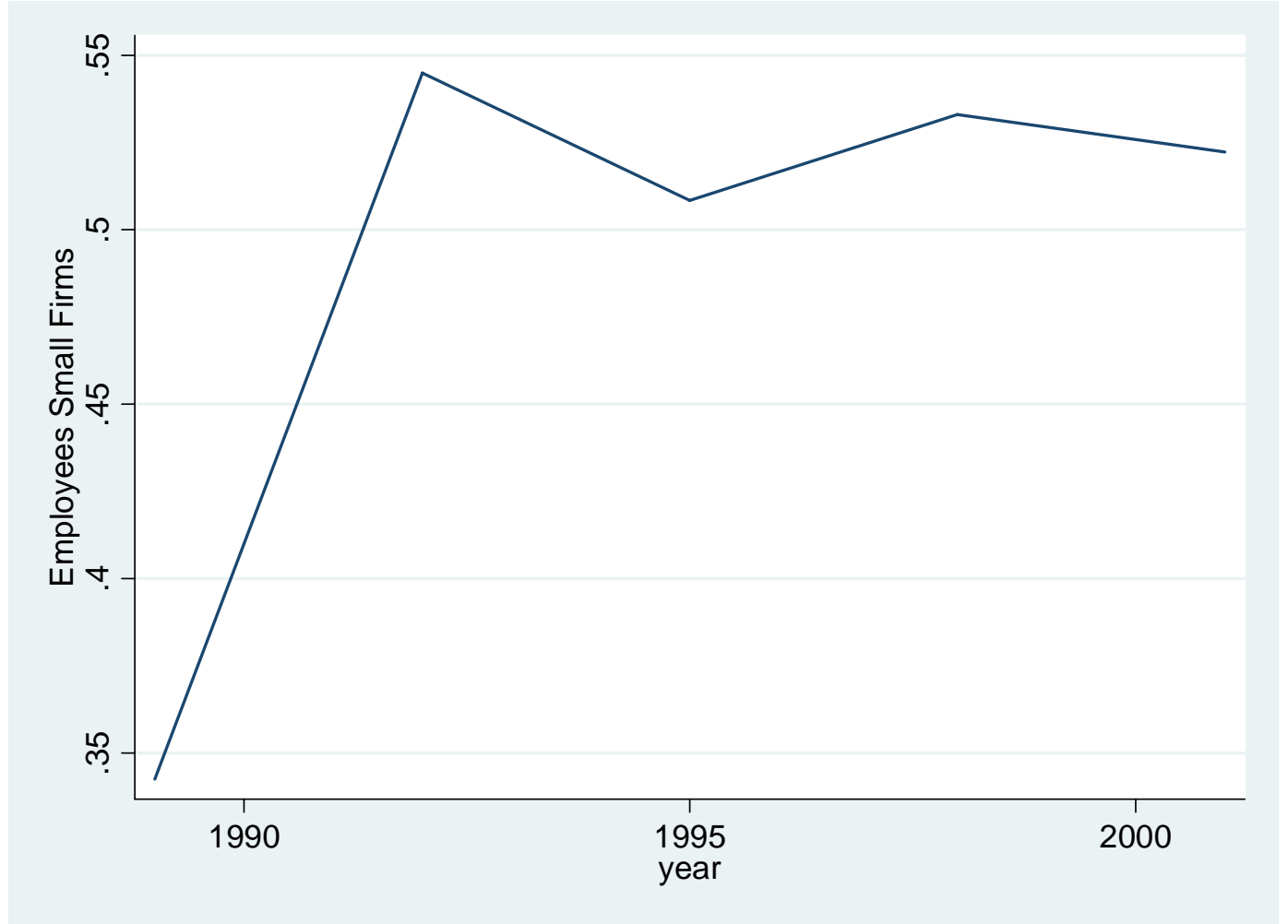

Figure 2

Credit Limit

This Figure reports the maximum amount that on average a household can drawn on credit cards and credit lines in 1992 U.S. Dollars.

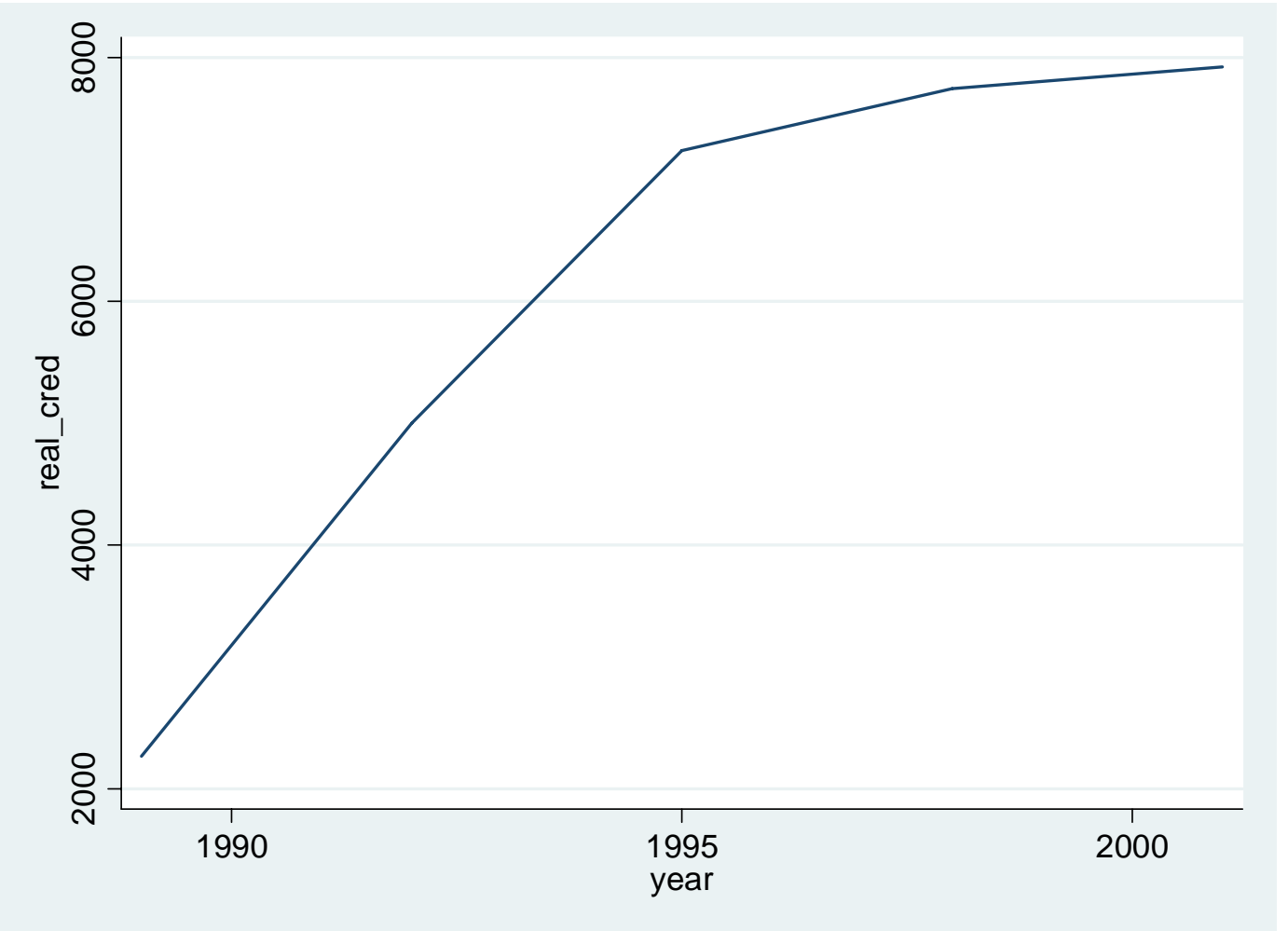

